\title{
Humorous phenomena in dramatic discourse
}

\author{
Marta Dynel \\ University of Łódź, Poland
}

\begin{abstract}
The paramount goal of this paper is to tease out a number of universal communicative phenomena which carry humour appreciated by the recipient of a drama series, based on data culled from a famous medical drama series, "House". This broad-range study aims to shed light on the humorous phenomena in dramatic discourse, which evinces greater similitude than comedy discourse. It is argued that conversational humour is prevalent in dramatic discourse, manifesting itself in rhetorical figures (e.g. creative metaphor or irony) and pragmatic types (e.g. teasing), which can also be categorised depending on whether or not they display genuine aggression. Two more humour types are also presented as part of conversational humour, namely: non-verbal expression and (non-)parodic impersonation. Additionally, several other sources of humour are distinguished, such as: a character's quirky behaviour (including participatory behaviour and impoliteness), uncanny events, situational irony, and deception. While the humorous capacity of such concepts has already been recognised, their position in the research on film discourse and in humour studies is not yet well-established. It will be argued that these phenomena manifest humorousness to the hearer on the second communicative level, the recipient, and are not necessarily humorous at the characters' level. All the humour forms distinguished are neatly captured by incongruity theory, specifically the incongruity-resolution model, coupled with superiority theory in the case of disaffiliative humour.
\end{abstract}

Keywords: dramatic discourse, "House", incongruity-resolution model, recipient, superiority theory

\section{Introduction}

This paper attempts to give a bird's-eye view of humour in dramatic discourse, which is here juxtaposed with comedy discourse, rather than be used as a blanket term covering the discourse of plays, film and series. Thereby, this article contributes to the nascent field of linguistic research on humour in film discourse, which is here used technically as an umbrella 
term covering characters' talk in films, series and serials (their differences regardless) representing all genres, with the focal one here being drama.

While semiotic and socio-cultural research on sitcoms and comedies is ample (e.g. Horton 1991; Marc 1997; Charney 2005; Dalton and Linder 2005; Trueth 2005; Mills 2005, 2009; Senzani 2010), linguistic works on their discourse are rather scarce (e.g. Gray 2006, Quaglio 2009). Likewise, relatively little linguistic research has been done into the nature of humour in comedy discourse, although a few exceptions can be found (e.g. Apter 1982a; Palmer 1987; Neale and Krutnik 1990; Stokoe 2008; Dynel 2010, 2011a; Brock 2011, Kozić 2012). In addition to this, a few studies of humorous mechanisms make use of comedy discourse as exemplification data (e.g. Vandaele 2002; Brône 2008). For example, Palmer (1987) forays into the semiotics of humour in films and television comedy. He conducts an analysis of dissociated phenomena grouped as non-verbal gags, comic articulation and comic identity, referring to the notion of peripeteia (incongruity) and syllogism (resolution). Taking sequences of conversation from "Friends", Stokoe (2008) discusses the way breaches of conversational rules function as legitimate humorous devices exploiting the juxtaposition of appropriate and inappropriate methods for performing dispreferred turns in adjacency pairs. However, the spectrum of sources of humour is much wider than that presented in the literature so far. Therefore, a more extensive discussion against a backdrop of humour theory is in order.

Central to the workings of humour in comedy is the fact that the fictional discourse of films operates on two levels of communication: the inter-character level, representing the fictional participants' interactions, and the recipient's (i.e. the viewer's) level, which concerns the viewer's interpretation of the former, as carefully devised by the film production crew dubbed the collective sender (see Dynel 2011b and the references therein). A mass-mediated artefact, therefore, displays two layers: the characters' fictional layer, by which recipients are enthralled, and the collective sender's layer responsible for the construction of the former.

Although numerous points of similarity can be found between real-life discourse and fictional discourse (see Dynel 2011c and references therein), the two display inherent divergences. This is relevant also to the nature of humour, whose manifestations may mirror those found in real conversations or may be typical solely of film discourse, which is orientated towards entertaining, yet not necessarily amusing, the recipient (Dynel 2011a). Entertainment is here seen as being a notion superordinate to amusement. Both concern viewers' diversion and inducing their pleasurable experience, yet only the latter promotes humorous effects. Cinematic ploys and careful construction of characters' interactions facilitate the occurrence of various humour forms sometimes based on communicative phenomena which would either be impossible in everyday discourse or, if materialised, would not carry any humorousness for any participant. This is because humour in film discourse is constructed by the collective sender (i.e. the film production crew) in order to amuse the recipient, via characters' utterances and actions, as well as events (Dynel 2011b).

Interestingly, some of the humorous forms are restricted to film discourse, being inconceivable in real-life talk. Humour may then impact on the code of realism/reality code (cf. Kozloff 2000; Bednarek 2010, 2011) or accuracy (Friend 2010) expected in drama. This is because humour may manifest itself in quirky characters or uncanny events practically impossible outside the fictional world (Quaglio 2009, Bednarek 2010), which results in what Palmer (1994) calls "suspension of logic", as is very pronounced in sitcoms. There is no denying that sitcoms are so rich in humorous characters, utterances and occurrences that their lack of verisimilitude in terms of humour emergence may be presupposed, even if characters' interactions should otherwise resemble real-life discourse. Sitcoms boast numerous indications of their orientation towards amusing the recipient (e.g. Mulkay 1988, Kuipers 
2008, Mills 2009, Kozić 2012), one of which is the presence of canned laughter. Thus, it can be stated that comedy feature films and sitcoms are enclosed within a humorous frame (see Dynel 2011d and references therein), and the humour therein cannot be evaluated in terms of real-life communicative patterns and daily occurrences, even if some overlap should be found.

In contrast, drama, both feature films and series, which are encompassed by an entertainment frame but not a humorous frame, should display more finesse, maintaining the veneer of similarity with real-life discourse and occurrences. As Palmer (1987) observes, humorous elements impact on the tonality of the realistic narrative and are tightly connected to it. Also, as Morreall (1983: 83) rightly notes, since humour involves "a jolt to our picture of reality, it is important in any extended sequence of humour stimuli, such as a comic monolog or play, to maintain an atmosphere in which the audience's sense of reality is preserved." Therefore, he continues, a film "which stays pretty close to reality and builds its incongruity on plausible events, can be amusing from beginning to end; by preserving our sense of reality and our ordinary expectations, it can jolt us with incongruities again and again." Although Morreall's (1983) suggestion that "wacky" comedies may not generate much humour sounds specious, his assertion is indeed germane to dramatic discourse. Most importantly, humour instances in dramatic discourse not only are less frequent than those in comedies, but also must be more realistic and must be plausibly interwoven into non-humorous discourse. In other words, the humour must sound plausible in the context of the characters' portrayal and interactions, reminiscent of real world people (even if not stereotypical, but showing idiosyncrasies) and their interactions. However, this does not mean that all humour in fictional talk must necessarily operate in real-life discourse according to the same patterns, given the intrinsic workings of films, with which recipients are familiar and which they take for granted (see Dynel 2011a, 2011b, 2011c).

Inasmuch as humour in dramatic discourse is constructed for the sake of amusing the recipient, it includes phenomena typical of film discourse which do not usually carry humour at the inter-character level, but may/should be perceived as humorous by the recipient (Dynel 2011a). This is not to say that all of the phenomena under this category are impossible in real situations. Unless facilitated by cinematic techniques (e.g. the viewer's participation in all relevant simultaneous/consecutive interactions), they can, and do, occur in reality. However, typically, they are not humorous from the perspective of the individuals involved.

On the other hand, in dramatic discourse, a large proportion of humour stems from what is known as conversational humour (cf. Kotthoff 1996, 1999, 2006; Coates 2007; Dynel 2009a, 2009b, 2011d; Norrick and Chiaro 2009), prevalent also in everyday conversations. Dramatic (as well as comedy) discourse abounds in witty turns and fast-paced conversational exchanges, which are the source of humour for viewers, and which are reminiscent of real-life discourse. This is why humorous turns produced by characters (but, obviously, conceptualised/reused by scriptwriters and rendered by actors) subscribe to the code of realism. Moreover, unintended linguistic impurities (e.g. stumbling over words, slips of the tongue or hesitation) in film discourse contribute to not only realism but also comic confusion (Kozloff 2000, Bednarek 2010), which can be conceptualised as unintentional humour, beyond the fictional speaker's control but purposefully rendered by the collective sender.

\section{The scope and methodology of the present study}

The paramount objective of this qualitative study is to compile a rich list of humour categories typical of drama discourse and to account for their workings, as interpreted by the hearer, notably the recipient. The "hearer" label is used in this paper as a generic term, 
irrespective of the actual participatory role an individual assumes, and regardless of whether the auditory channel is involved, as is the case of non-verbal humour. This term captures also the viewer's role, specifically referred to as the "recipient". On the other hand, the "speaker" is used as a generic term for the producer of a message, notwithstanding the means of communication.

Such an extensive list of humorous phenomena is in demand, given the widespread interest in humour in films and series, while the literature on humour does not offer much systematic research in this respect. The humorous phenomena are elucidated in the context of their workings in characters' interactions in drama operating on two communicative levels and savouring of real-life conversations. Although this analysis is conducted on the basis of one series, and examples are thus specific to it, it is argued that the categories of humour distinguished are by no means restricted to this series and may be prevalent also in other films, series and serials, even if their second-order realisations may vary. A disclaimer should be made at the outset that the categories of humour enumerated here may overlap in various ways, showing co-dependence, while the labels employed will depend on particular research foci.

This study is based on a corpus of examples taken from "House MD" (2004-2012), officially classified by its authors as a medical drama series. In each episode, Dr House and his team (whose members change a number of times in the span of the eight seasons released) are absorbed in a peculiar medical case. Scenes in which the doctors try to solve the central conundrum as well as minor cases of clinic patients are intertwined with those presenting changes in their personal lives. The popularity of the series can be credited to primarily to the charismatic lead character, who is extremely witty but exhibits an immensely abrasive personality. Both these features are manifest in his interactions with his team members (altogether: Dr Eric Foreman (also his supervisor, and employer in season 8), Dr Robert Chase, Dr Allison Cameron, Dr Chris Taub, Dr Laurence Kutner, Dr Remy 'Thirteen' Hadley, Dr Martha Masters, Dr Jessica Adams, and Dr Chi Park); employer, and his girlfriend in season 7, Dr Lisa Cuddy; best friend, Dr James Wilson; as well as patients, and other characters who appear in one or a few episodes, such as House's former fiancée and her husband. The majority of examples presented here come from the eponymous character. This is, however, not meant to suggest that other characters are not responsible for the emergence of humour in the series.

Notwithstanding the fact that this is a qualitative study, not a quantitative one, attention is paid to the sources of humour which are prevalent in the series in focus and, therefore, may be considered more significant. Albeit taken from one television series, the types of humour elucidated are claimed to be universal. Each of the examples quoted may present more than one humorous phenomenon, but only that in focus of a given section will be addressed, both for the sake of clarity of presentation and for reasons of space. The workings of humour categories are discussed against the backdrop of relevant humour research on the specific categories of humour, as well as of two fundamental approaches to humour: incongruity and superiority theories, whose premises will now be succinctly reviewed.

\subsection{Incongruity theory}

Support is here given to a view that the notion of resolvable incongruity (for a historical overview, see Grimes 1955; Keith-Spiegel 1972; Morreall 1983, 1987, 2009; Attardo 1994; Martin 2007) captures the workings of all humour, as proposed in both linguistic and psychological literature (Suls 1972, 1977, 1983; Shultz 1972; Forabosco 1992, 2008; see 
Attardo 1994; Ritchie 2004; Martin 2007; Dynel 2009a, 2011e, 2012b, for further discussion and references therein).

On its most general reading, the incongruity-resolution model presents incremental humour interpretation in the following way: the hearer interprets a stimulus until he/she encounters and recognises an incongruity, which he/she then resolves according to an adequate cognitive rule, thereby rendering the incongruous element somehow congruent. While originally proposed for jokes and captioned cartoons (Suls 1972), as well as riddles (Shultz 1972), and typically employed in reference to canned jokes (see Dynel 2009a and the references therein), broadly understood, the incongruity-resolution model is applicable also to other, if not all, forms of humour, which the present discussion on dramatic discourse is meant to bear out. Incongruity, cognitive mechanisms and incongruity resolution may display innumerable manifestations, while a complex example may be interpreted in more than one way, presenting several incongruities.

Incongruity is a nebulous notion which has been defined in numerous, yet not incompatible, ways. On the whole, incongruity may be understood either as a mismatch stemming from the structural features of a stimulus or as a clash with expectations and mental patterns (Morreall 1989, 2009), as it is known in cognitive (both linguistic and psychological) studies, with each instance of humour being explicable in the light of either. Morreall (1983) lists various types of structural incongruities central to non-verbal and verbal humour. In terms of the former, next to deficiencies of various types, he raises the notion of ostensive similarity and regularity in a pattern (which is non-prototypical or surprising), as well as the violation of physical laws. With reference to verbal humour, he enumerates incongruities in operation on various levels of language: sounds (such as alliteration, rhyming or spoonerisms), semantics (which involves juxtapositions of ideas), and pragmatics (violation of language norms and rules or logical principles, appeal to quasilogical principles, lack of fit between the statement and reality/the state of affairs, or a mismatch between an utterance and the accompanying non-verbal expression). However, in his approach to incongruity in verbal humour, Morreall (1983) neglects entirely incremental text development, which is of crucial importance to the workings of jokes (and possibly other forms of humour as well), as tacitly assumed in the incongruity-resolution approach (see Dynel 2009, 2012). Incongruity may be perceived between two elements of a text or discourse, which activate incongruous meanings. This general pattern displays numerous manifestations, as does incongruity in non-verbal humour. Morreall's (1983) list is by no means exhaustive, but it does indicate the forms incongruity may take. Remarking on the futility of any attempt to compile an exhaustive list of humorous incongruities, Morreall states: "Wherever there is a principle to be violated or regularity to be upset, there is room for incongruity and so for humour" (1983: 82). Whatever its manifestation is, structural incongruity is compatible with incongruity as a cognitive phenomenon, which the discussion of examples below will also bear out.

In cognitive terms, incongruity is understood as "the discrepancy between two mental representations, one of which is an expectation [...] and the other is some idea or percept" (Suls 1983:41) or "a conceptual shift, a jolt to our picture of the way things are supposed to be" (Morreall 1983: 60). This is why the notion of violated/defeated expectations tends to be proposed as being of primary importance to humour experience (e.g. Suls 1972, 1983; Nerhardt 1976; McGhee 1979; Morreall 1983, 1987, 2009; Ziv 1984; Coulson 2001; Ritchie 2004). Nevertheless, a question arises as to whether hearers always develop any expectations about the forthcoming part of a joke (cf. Dynel 2009), an interaction or an event, while they do make on-line inferences as new information is added. In many, if not most cases, that backgrounded expectations have been violated can only be assessed post factum. It is only with the benefit of hindsight that the hearer may acknowledge that he/she would never have 
envisaged a given stimulus (an utterance, an event, an image, etc.). Thus, rather than be considered in terms of violated expectations, this feature of humorous incongruity should be deemed surprise and novelty (e.g. Suls 1972; Forabosco 1992, 2008; Martin 2007; Morreall 1983, 2008; Dynel 2009a, 2009b, 2011b; and the references therein). The contention that surprise, and hence novelty, unexpectedness, and suddenness, are prerequisites for the appreciation of humour is rooted in philosophical tradition (Hobbes 1996 [1651], Kant 1951 [1790]). However, as Hurley et al. (2011) aver, people are not capable of anticipating countless phenomena and occurrences they experience and yet are not continually surprised by them. They are surprised, Hurley et al. (2011) argue, by what they have expected not to happen, nurturing expectations about something else instead. With the violated expectations claim refuted, it may be concluded what surprises people is what they have not expected to happen and what is hence unexpected (whether or not holding alterative expectations which are thus indeed violated) and, simultaneously, what cannot be effortlessly assimilated. Humour displays surprising novelty and originality, suddenly catching the hearer off guard with something that they cannot smoothly assimilate (Morreall 1983).

In the light of all this, incongruity is here defined as a cognitive state caused by a surprising/unexpected stimulus which diverts from the cognitive model of reference (Forabosco 1992, 2008). The concept of a model "highlights the comparative and interpretative aspect: a model is a sort of preliminary representation and minitheory which the subject uses in his relationship with reality" (Forabosco 1992: 54, 2008: 48) when interpreting incoming stimuli. The cognitive model of reference is here argued to capture any conceptual abstraction and to be an umbrella term for what is widely known as scripts, schemata, frames, as well as more transient knowledge structures in the context of the situation at hand. Incidentally, these notions have already been applied in humour research in various frameworks (e.g. Koestler 1964; Norrick 1986, 1987; Coulson 2001; Coulson et al. 2006; Wyer and Collins 1992; see Martin 2007; Dynel 2009, 2011e, 2012), which also necessitates a distinct super-ordinate concept pertinent to the whole gamut of humorous stimuli. When an incongruity emerges, the cognitive model of reference may have already been active in the hearer's mind, or it may be activated by an utterance or a different stimulus which simultaneously displays incongruity with it. Additionally, incongruity is relative to an individual's cognitive model of reference which depends on his/her experience (cf. Morreall 1983), but humour typically resides in universal ones, thereby being available within one culture or across cultures.

Encountering an incongruity, the hearer has a relevant cognitive model of reference, part of his/her conceptual system, violated. This is what Morreall (1983) calls a conceptual shift from the expectations (here, cognitive model of reference) of what the situation should be like to an awareness of the situation not being such. A conceptual shift, in his view, may be based on "simple surprise", which involves a new stimulus, or on incongruity. However, this unequivocal differentiation is not well-founded [1], for, as Morreall (1983) himself underscores, all humour exploits an element of surprise, which is crucial for incongruity. Also, a perceptually surprising stimulus can be interpreted as incongruous. Experiencing incongruity which centres on "simple surprise", the hearer is confronted with a surprising, incongruous stimulus which cannot be assimilated into any familiar conceptual category subscribing to the cognitive model at hand.

Perceptually incongruous humour, whether verbal (e.g. a new word) or non-verbal (e.g. a strange facial expression), rests on the violation of the cognitive model of reference embracing what is possible or likely, generally or in the present context. Following McGhee's $(1971,1972)$ train of thought, the perception of humour, based on a stable perceptual grasp of the real world, involves the hearer's "confidence in the impossibility or improbability of the 
stimulus elements occurring as depicted" (1972: 66), which is known as fantasy assimilation [2]. Rothbart (1976) subscribes to this statement, adding that fantasy assimilation occurs when incongruity resolution does not take place. However, fantasy assimilation may be conceptualised as a type of resolution which operates on a simple cognitive rule of acknowledging that something is/was impossible or highly unlikely to happen and yet it did. As Forabosco (2008: 49) rightly asserts, next to incongruity, humour experience necessitates an element of sense, which makes a stimulus "cognitively acceptable" and which is acquired via the identification of a cognitive rule, whereby the hearer exerts mental control of a stimulus, gaining cognitive mastery of it. It is here argued that resolution operating on various cognitive rules is then of crucial significance to humour appreciation. The argumentation of the authors (Nerhardt 1976, Rothbart 1976, Pien and Rothbart 1976, see Martin 2007) supportive of incongruity alone as the mechanism of humour experience can thus be dismissed on the grounds that after incongruity arises, the hearer must rationalise it somehow. Incongruity resolution may sometimes be tantamount to the hearer's conscious acknowledgement of incongruity's presence, and thus cognitive mastery of a stimulus, with no clear cognitive rule being specified (cf. Ruch 1992).

Humorous incongruity may be considered similar to Festinger's (1957) cognitive dissonance, which is induced by nonfitting relations among cognitions or beliefs [3], and which automatically motivates people to reduce it. Contrary to cognitive dissonance, however, incongruity conducive to humorous effects cannot be fully resolved, with residual incongruity (Forabosco 2008) remaining. In other words, the resolution of incongruity is never complete and some tension lingers (Suls 1983; Mulkay 1988; Ruch and Hehl 1998; Forabosco 1992, 2008; Attardo and Raskin 1991; Oring 2003), which is the sine qua non for humour experience, insofar as the final stage of humour experience is grounded in the hearer's oscillation between congruity and incongruity [4] (Suls 1983; Ruch and Hehl 1998; Forabosco 1992, 2008; Dynel 2011e).

Finally, several conditions must be met so that partly solvable incongruity can be considered humorous. Most important are: a facilitating, i.e. pleasant and safe, context (Rothbart 1976), the right emotional climate (Mulkay 1988) or a playful frame of mind (Apter 1982 b, cf. Lyman and Waters 1986, Ruch 2008). Similarly, in Morreall's (1987) view, a cognitive shift promoted by incongruity must be taken playfully by an individual disengaged from ordinary concerns. It could be concluded, therefore, that to find it humorous, the hearer must process an incongruity in a state of cognitive safety, which is largely dependent on the nature of the stimulus involving incongruity. In a prototypical situation of watching a film, the recipient is in a state of cognitive safety at all times.

\subsection{Superiority theory}

Whenever humour experience involves the butt or the target, at whose expense the hearer (here, primarily the viewer) is meant to be amused, incongruity theory can be neatly interwoven with superiority/disparagement theory (see e.g. Berlyne 1969, La Fave 1972, Zillmann and Cantor 1976, Gruner 1978, Zillmann 1983, Morreall 1983, Morreall 1987, see also Martin 2007, for a summary of experimental work, see Ferguson and Ford 2008). Superiority, together with derogation and aggression it involves, is by no means a universal mechanism of humour but an adjacent factor contributing to the hearer's satisfaction and mirthful pleasure.

The state-of-the-art picture of humour research from the superiority perspective is very rich. There are numerous accounts of humour which victimises the target via disparagement, belittlement, debasement, degradation, humiliation, etc. The pivotal tenet of superiority theory 
is that humour stems from enhanced self-esteem thanks to a downward comparison, a view first endorsed by Hobbes (1996 [1651]) and later zealously supported by other authors (La Fave 1972, La Fave et al. 1976, Gruner 1997), or a feeling of superiority or triumph based on the recognition of the target's infirmities, foibles, weaknesses or misfortunes. Also, superiority originates in one's realisation that one does not display the characteristics, such as stupidity or clumsiness, which the target does.

Most accounts of superiority theory address the relation between the speaker (and rarely the amused hearer) and the butt. From among the various approaches, the most plausible one appears to be the disposition theory of humour (Zillmann and Cantor 1972, 1976; Cantor and Zillmann 1973), according to which the hearer's appreciation of humour correlates negatively with the favourableness of his/her disposition towards the disparaged target and varies directly with the favourableness of his/her disposition towards the disparaging speaker. The authors argue in favour of affective disposition, a continuous but transitory variable ranging form negative affect and neutral indifference to positive affect (Zillmann and Cantor 1976, Zillmann 1983). Contrary to the alternative proposals, this one does not necessitate the use of arbitrary classificatory terminology of the target, which is useful in the analysis of most disparaging humour in focus here (as opposed to canned jokes).

Also, the authors develop the disposition theory of drama and comedy (Zillmann, 1980, 1983, 1996, 2000; Zillmann and Cantor 1976) which projects viewers' enjoyment or dejection of characters on the basis of the dispositions formed on the basis of moral assessments. In line with the central premise of this account, dispositions towards characters are mapped onto a continuum ranging from extreme hatred, through indifference, to adoration. Comedy and humour capitalise on insults, humiliation and mishaps, yet not merely the benefaction of the characters to whom the viewers display positive dispositions.

Most importantly, whereas the other models seem to merge the speaker with the amused hearer, the disposition-based proposal distinguishes between the two roles. Thus, to appreciate disparagement humour, an individual must at least display the attitude of supreme indifference to the victim and must not sympathise with the latter, at least not to an extent that would block the humorous effects. This seems to be the case of most disparagement humour in "House", for the viewer is expected to display positive attitude to, and affiliation with, the eponymous character, while not sympathising, at least at a given moment, with the individual disparaged. Another crucial merit of this approach is its potential to account for transitory/momentary negative attitude to a target whom one does like otherwise (Zillmann and Cantor 1976). This also holds in the case of film discourse and explains the viewer's lack of affiliation, or even disaffiliation, even if only momentary, with the butt, whom one may otherwise like.

However, while the authors of the disposition account stipulate that even though selfenhancement does arise, "benefaction or enhancement of one party by another is not a condition for enjoyment in this model of disparagement humour" (Zillmann 1983: 92), it may be argued that this is the driving force of disparaging humour in "House", where the focus is on the speaker's position and his wit. Superiority may be consequent upon the speaker's manifestation of aggression and wit, leading to "heightened self-esteem" (La Fave et al. 1976: 96) on the speaker's part, with the butt's position being of lesser significance. This is in tune with the present definition of disaffiliative humour based on Martin et al.'s (2003) conceptualisation of aggressive humour. It is the enhancement of the speaker's self via witty aggression that offers the basis for the humorous effects experienced by the hearer. The viewer is not preoccupied with the butt's feelings, which is facilitated by the construction of interactions and the way the camera shows them. In some cases the response is not provided at all, while in others the individual attacked reciprocates, which boosts the humorous 
potential of an interaction. If, on the other hand, the butt is presented as being deeply offended or miserable, the recipient might not experience merriment.

Also, disparagement can be humorous as long as the interpreter can attribute his/her amusement, a type of misbehaviour, to something different from the disparagement per se, mainly the manner in which something was done or said (Zillmann and Cantor 1976, Zillmann 1983). This is why superiority can be neatly grafted on incongruity theory. Thus, superiority underlying some humour consists in the use of incongruity for disparaging purposes, or in the emergence of incongruity which causes an individual's inferiority (cf. La Fave et al. 1976, Apter and Smith 1977, Suls 1977, Zillmann 1983, Palmer 1994, Vandaele 2002, Morreall 2008). Also, as Morreall (2008: 234) observes "most of the incongruities we laugh at, especially in comedy, are human shortcomings - ignorance, stupidity, awkwardness, mistakes, misunderstandings, and moral vices. The Incongruity Theory would say simply [5] that it is the out-of-placedness of these shortcomings that we enjoy." Even though it does not focus on the disparagement as the direct source of humorous experience, the incongruityresolution model may be combined with the superiority approach.

With these bedrock assumptions presented, humour types in dramatic discourse can now be discussed.

\section{Conversational humour}

Dramatic film talk may abound in conversational humour, typical also of real-life discourse, with its numerous manifestations, coinciding with stylistic figures and pragmatic categories (cf. Dynel 2009b, 2011f), some of which will be presented here. Also, units of conversational humour can be divided according to two other criteria: (lack of) communication of nonhumorous meaning and (lack of) genuine aggression.

Firstly, differentiation is proposed between non-humorous utterances imbued with humour and humorous utterances enclosed within a humorous frame (see Dynel 2011d and references therein). The former overtly carries relevant meaning outside the humorous frame, with humorous effects being of secondary importance; whereas the latter does not appear to do thus, displaying primarily the goal to induce a humorous response in the hearer. Actual instances need not coincide with either of these two ideal types, showing various degrees of humorously tinted or veiled meaning conveyed.

Secondly, a distinction can be drawn between conversational humour which involves no aggression or only humorous aggression, and conversational humour which capitalises on genuine aggression, i.e. aggression which is not part of the humorous frame and by means of which the speaker means to attack an individual or individuals, thereby inviting humour to be enjoyed by another one. Thus, one may distinguish between affiliative (cf. Martin et al. 2003) and disaffiliative humour (Dynel 2010, 2012a). The former is benign and friendly, for, even if some aggression should be present, it is pretended, or at least motivated by the speaker's benevolence towards the butt, as is typically the case of friendly teasing. By contrast, the scope of disaffiliative humour coincides with Martin et al.'s notion of aggressive humour, which they define as that which is used "to enhance the self at the expense of others" (Martin et al. 2003: 48). Essentially, "disaffiliative humour" is a blanket term for various conversational units which are intended to disparage the butt/target, and thereby to amuse another hearer, other than the butt. Only this type of conversational humour is captured by the superiority account. The label "disaffiliative humour" should not be equated with "aggressive humour" or "disparagement humour", inasmuch as these prevalent labels refer also to 
playfully aggressive humorous units (see e.g. Gruner 1997), whose workings are not tantamount to genuine aggression.

\subsection{Stylistic figures}

Humour is typically imaginative, creative, inventive, and original. As Morreall (1983: 91) puts it: "Instead of following well-worn mental paths of attention and thought, we switch to new paths, notice things we didn't notice before, and countenance possibilities, and even absurdities, as easily as actualities". In both real-life discourse and in film conversations held by characters, conversational humour tends to originate in vivid imagery and linguistic creativity (cf. Culpeper 2011), based on novel stylistic figures and innovative deviations from stylistic norms (Leech 1985), collectively dubbed colourful language (Partington 2006, 2008a; Dynel 2009b). This term covers utterances couched in a wide array of creative linguistic phenomena, such as: euphemisms, paradoxes, metaphors, irony (which will be briefly discussed below), wordplay, register clashes, innovative collocations, neologisms, allusions, and the whole gamut of other novel stylistic modifications. Colourful language is typically employed to convey relevant meanings and to promote humour, and hence it can be conceived primarily as non-humorous utterances imbued with humour. Fictional speakers spontaneously employ such forms to amuse their interlocutors, come over as being witty, or for markedly different reasons (cf. Example 1). Ordinary language users, even if not all, happen to do likewise. Obviously, the scriptwriters' underlying goal, when inventing (not necessarily spontaneously) or quoting the expressions they know from other sources, is to amuse the viewers and further the plot.

\section{Example 1}

[House is on clinic duty. A mother has come with her four-year-old daughter, suspecting epilepsy in her. Having familiarised himself with the symptoms, House offers a diagnosis.]

1. House: You mix rocking, grunting, sweating, and dystonia with concerned parents and you get an amateur diagnosis of epilepsy. In actuality, all your little girl is doing is saying "yoo hoo" to the hoo hoo.

2. Mother: She's what?

3. House: Marching the penguin. Ya-ya-ing the sisterhood. Finding Nemo.

4. Girl: [laughing] That was funny.

5. House: It's called gratification disorder. Sort of a misnomer - if one was unable to gratify oneself...that would be a disorder.

6. Mother: [covering the girl's ears] Are you saying she's masturbating?

7. House: [through the corner of his mouth] I was trying to be discreet - there's a child in the room!

Episode 21, season 2

House uses four creative lexical items (1 and 3) to refer to the tabooed activity in the child's presence. All are euphemistic, and each presents its distinct features, which coincide with second-order textual incongruities based on uncanny juxtapositions: the first one, "saying yoo hoo to the hoo hoo", is based on a slang term for female genitalia and a rhyme, and thus incongruity based on surprising sound repetition (which is ultimately accepted as being possible); the second one "marching the penguin" may be considered metaphorical (see example 3 below); the third and fourth ones capitalise on popular culture allusions (cf. Nash 1985; Norrick 1987, 1993, 1994) to a comedy drama about female friends ("Divine Secrets of the Ya-Ya Sisterhood") and a famous cartoon for children whose plot revolves around a search for a fish ("Finding Nemo"), both of which present incongruity in the context at hand. Each of these incongruities is resolved, once the covert meanings of the lexical items are discovered. On a more general level, this sequence of creative euphemisms displays overt incongruity, the recipient's cognitive model of reference being his/her mental lexicon, so long 
as he/she does not know these as slang expressions. This is also the source of humour from the girl's perspective (4). Whether or not purposing to do so, House does elicit a humorous response from the girl, who probably cannot make any sense of the terms but finds them incongruous. Given the contextual information provided, however, the recipient can infer what House has in mind, thereby resolving this incongruity. Also, incongruity may be perceived between the innovative lexemes and the cognitive model of inference of the medical terminology that a doctor should be using. This incongruity is also resolved in the light of the child's presence and House's underpinning motivation. On the pretext that he does not want the girl to hear the proper medical term (which probably would not mean much to her) (7), he aims to make fun of the mother by deploying the creative terms, which she finds elusive (2), and to rebuke her for having attempted her lay diagnosis of the symptoms, whose explanation is quite trivial.

Among many other rhetorical figures used for humorous purposes, worth mentioning is paradox, inasmuch as it has not received a lot of attention in humour studies. A paradox is understood as a statement which involves internal contradiction, which can be conceived as incongruity.

\footnotetext{
Example 2

[House is talking to Mr Weathers, the organ donor's father, to check if the young man's organism was healthy and drug-free.]

1. Mr. Weathers: I told you my son didn’t do cocaine.

[House pulls a pill bottle from his pocket and dry swallows it in front of Mr. Weathers]

2. House: Druggies are not known for their honesty. Trust me on this one.

Episode 2, Season 8
}

Having swallowed a pill in front of his conversationalist and given him reasons to believe that he is addicted to the medicine (of which regular viewers of the series are fully aware), House verbalises an utterance (2) which displays an overt contradiction in the context. An incongruity can be detected between the piece of advice on addicts' dishonesty and the speaker's, an addict's, request to trust him. The resolution of this incongruity appears to coincide with the acknowledgement that it cannot be logically reconciled, whereby cognitive mastery of the verbalisation is gained.

While the humorous potential of euphemistic lexemes and paradoxes has not been widely discussed so far, several authors have observed the humorousness of metaphor which typically evinces novelty (Fónagy 1982, Mio and Graesser 1991, Pollio 1996, Grady et al. 1999, Attardo 1994, Veale 2003, Veale et al. 2006). According to the interpretative model advocated here, incongruity is manifest between the literal meaning of a metaphor and the hearer's cognitive model of reference encompassing the hearer's view on the speaker's communicative intention in a given context, while its resolution coincides with discovering the implied meaning, predicated on the logical rule of finding the tertium comparationis, the common feature of the source domain relevant to the target domain. Humorous metaphors are typically creative and diaphoric (see MacCormac 1985), which obstructs the process of comprehension. As argued elsewhere (Dynel 2009c), the humorous potential of creative metaphor presents itself in: the unavailability of the tertium comparationis, the elusiveness of the vehicle's salient feature applicable to the target domain, internal incongruity in the vehicle, or the disparity between the domains, two of which are present in the example below. Whilst example 3 does not show this problem, the humorous potential of metaphors may also be rooted in the methods by which conversationalists interweave metaphors into their verbal exchanges (see Dynel 2012c). 
Example 3

[House meets his team, Foreman, Taub, Thirteen and Chase in their diagnostics room. They have a new female patient.]

1. Thirteen: And she's in an open marriage.

2. Foreman [shaking his head, amused]: That's not interesting. It's just weird.

3. House: Know what's weirder? That other humans are monogamous in the first place. No other species on the planet mates for life and if you're gonna bring up swans, they cheat like everybody else. They just have better PR than rabbits.

[...]

4. Taub (rolls his eyes): A functional open marriage is like a unicorn. It's a mythical creature that doesn't exist. Someone always ends up unhappy.

[Later, the team meet again.]

5. House: He's lying.

6. Chase: Guy's got a license to drill. Why would he lie about not using it?

7. House: That's not the lie. The lie is that he gives a crap about how his wife feels. If they're both screwing around, that's one thing. But if she has a piece on the side and he doesn't, the only way he'd be okay with that is if he's betraying her in some other way that, in his mind, makes them even. My unicorn isn't a unicorn. It's a donkey with a plunger stuck to its face.

Episode 19, season 6

In the two interactions quoted above, two humorous metaphors can be found. Firstly, House employs a novel personification metaphor (3), using the notion "PR" ("public relations"), inherent in human professional contexts, in reference to rabbits and swans. The juxtaposition of the two domains, the socialised human world and the animal world currently addressed, is the source of incongruity, resolved once the key feature of PR, the shaping of relationships shown to the world, is elucidated and considered relevant to animal behaviour. In the same interaction, Taub contributes a creative, albeit not necessarily humorous, simile (4), whereby he compares the notion of an open marriage to a unicorn, the tertium comparationis being their non-existence, despite their presence in discourse. Capitalising on this conceptualisation, House later metaphorically depicts his perspective on the way the patient's husband makes use of his open marriage (7). In the light of House's description, the recipient construes an internally incongruous image of a donkey with a plunger clung to its face, the resolution coming with cognitive mastery over the two incongruous elements: the animal and the domestic device for pipe cleaning. This absurd image, which flies in the face of anything possible and which cannot be assimilated, is the source domain. The global resolution of House's incongruous metaphorical utterance rests on understanding that this image does indeed resemble a unicorn in its shape but is not one, and it is thus deceptive. Overall, House suggests that the man only pretends to enjoy his open marriage, while hiding something.

Irony is another stylistic figure frequently perceived as inducing humorous effects (e.g. Dews et al. 1995; Kumon-Nakamura et al. 1995; Attardo 2000, 2001; Kotthoff 2003; Partington 2006, 2007; Kapogianni 2011; Hirsch 2011). It is here argued that irrespective of its type, irony will be humorous thanks to the incongruity between the literal meaning of an utterance and the hearer's cognitive model of reference encompassing the his/her view on the speaker's beliefs. The speaker-intended meaning needs to be sought, given: the hearer's background knowledge, the situational context, previous conversational turns, and other ironic cues. To resolve the incongruity, a recipient must arrive at a congruent implied meaning necessarily carrying evaluation, according to an appropriate cognitive rule depending on a type of irony involved.

\section{Example 4}

[House tells a clinic patient, Whitney, that she is pregnant, which she will not believe.]

1. Whitney: I'm a virgin. So's my fiancé.

2. House: I believe him. 
3. Whitney: Aren't there other ways I could get pregnant like sitting on a toilet seat?

4. House: Absolutely. There would need to be a guy sitting between you and the toilet seat. But yes, absolutely.

5. [Whitney looks at him imploringly]

Episode 11, season 5

In the interaction above, House's turn (4) in response to the patient's question (3) involves an ironically-loaded word "absolutely", which emerges as being incongruous, given the context and co-text. The hearer cannot interpret the speaker's utterance as truthful, in the light of the general knowledge of the conception process, as well as the earlier part of the interaction indicating the speaker's disbelief in the woman's virginity (2). Lest the first use of the word should not be understood as being ironic, House repeats it having provided more information, which subverts the main premise of Whitney's question. Thus, the incongruity between the literal meaning of the evaluative word and the speaker's belief is now transparent. As a result, the hearer seeks its resolution, which comes with an understanding that House both provides a negative answer to and criticises the question, the implicit meaning being "Absolutely not/By no means is this possible! And your question is silly". The patient is the only hearer to House's ironic utterance at the inter-character level, and, in accord with the speaker's intention, she does not find it humorous, which can be gathered based on her non-verbal response (5). The recipient, on the other hand, may find humour in the irony, as predicted by the incongruity-resolution model and superiority account. Experiencing cognitive safety, and not sympathising with the patient, the recipient derives pleasure from House's disparagement of her and his superiority. On this reading, the speaker's irony displays incongruity typical of impoliteness (see section): the cognitive model of reference of doctor-patient talk.

One of the most significant figures known is humour studies is punning/pun, which occurs in jokes, headlines and, most importantly, in conversation and have been discussed from numerous perspectives in the literature (see e.g. Dynel 2011f). Puns in conversation may manifest themselves as interactional puns (cf. Norrick 1984, 1986, 1993) or reformulation puns (Partington 2006), which can be seen as a peculiar form of trumping (Veale et al. 2006, Brône 2008) based on the speaker's pretended misunderstanding of the preceding turn, which prompts him/her to skew the intended meaning and activate another one (Dynel 2009b). However, puns may also be interwoven in fictional or real-life discourse in the form of witticisms. Both of these cases are exemplified in the interaction below.

Example 5

[House and Wilson are taking a cooking class. House is shaping meatballs, and Wilson is stirring sauce.]

1. Wilson: Roll your meatballs and keep an open mind.

2. [A scheming smirk is drawing on House's face]

3. Wilson: How hard are you trying not to make a ball joke right now?

4. House: [looking past Wilson] They're smoking. [Wilson looks at him questioningly] Your balls.

5. Wilson: Ow. No, no. They're browning way too fast.

[...] [House pours some vinegar into a cup and is brushing it onto the meatballs in the frying pan.]

6. Wilson: That actually makes sense. You might've... saved my balls.

7. House: [smiling] That's the spirit.

Episode 3, season 6

By his utterance (1), Wilson unwittingly invites House to observe a hidden, unintended meaning in it, which involves a taboo, widely recognised as fertile ground for humour. House does not manage to retort by making an incongruous contribution, insofar as Wilson recognises his intentions (3), based on his non-verbal expression (2). On the other hand, in his last turn in this interaction (6), Wilson makes a pun singlehandedly, simultaneously activating two meanings of the ambiguous word. Facilitated by the previous part of the conversation, 
House (7) and the recipient consecutively activate the two alternative senses, thus gleaning two meanings of this utterance ("You've saved my dish" and "You've saved me"), both relevant in this context (cf. Dynel 2010b). The surprising coincidence of two meanings in one form gives rise to incongruity (cf. an utterance's carrying a single relevant meaning), whose resolution depends on an understanding that this is possible, albeit rare.

\subsection{Pragmatic categories}

Conversational humour can also be approached from the perspective of pragmatic, i.e. functional, categories, the most prominent of which is teasing (e.g. Norrick 1993; Hay 2000; Boxer and Cortés-Conde 1997; Lampert and Ervin-Tripp 2006; Haugh 2010; Geyer 2010; Partington 2008b; Dynel 2011d and references therein). This is a nebulous concept showing a wide range of manifestations and blurry boundaries, as the various studies indicate. It is here defined as a humorous practice embracing jocular utterances performing a variety of pragmatic functions (such as mock challenges or threats), carrying humorous force, but no genuine aggression, even if ostensible aggression should be present. A tease is generally not to be treated as truth-oriented, but some implicitly conveyed meaning may, and frequently does, arise as well (see Dynel 2011d). Teases tend to be couched in overt untruthfulness, as the speaker transparently pretends that he/she believes that something is the case (yet usually not being ironic).

The concept of banter (Norrick 1993, Chiaro 1992, Dynel 2009b) overlaps with teasing, but it is more rarely used. However, two differences between banter and teasing can be observed. While teasing may be restricted to one turn only, banter is typically developed across turns. Secondly, banter appears to be geared towards mutual amusement solely, with practically no meanings being conveyed outside the humorous frame, other than general meta-messages concerning mutual friendship. Therefore, banter may assume the form of a humorous fantasy sequence (Hay 1995) or joint fantasising (Kotthoff 2007), i.e. participants' contributions comprising an unreal/surreal picture. Therefore, banter is defined as a "rapid exchange of humorous lines oriented toward a common theme, though aimed primarily at mutual entertainment rather than topical talk" (Norrick 1993: 29). Incidentally, a different conceptualisation of banter is proposed in impoliteness studies (e.g. Haugh and Bousfield 2012).

Example 6

[The team have been assigned the case of a new patient, a political consultant, but House finds this case uninteresting, while Foreman, an Afro-American, insists that they should take it.]

1. Foreman: Senator Anderson sent this case to us, and personally requested we take a look. That's reason enough for me.

2. House: Black guy campaigning for the opposition? Does Obama know about this?

3. Foreman: I tried calling him on the brother hotline. He didn't pick up.

Episode 6, season 7

Interestingly, this example of teasing/short banter makes use of a cultural allusion to the nonfictional presidential elections in the USA, thanks to which the fictional and real word mesh. In his utterance (2), House jocularly reproaches Foreman for supporting the opposition, a white candidate. The fact that House brings up the topic of campaigning is conceptually incongruous given the conversational context. So is the question that follows. Obviously, House cannot mean to associate a doctor's duty with political views and cannot expect Foreman to have contacted Obama, which is why his utterance must be treated as being purely jocular. This realisation is then the essence of incongruity resolution performed by 
both by the addressee and the recipient. Replying to House's challenge, Foreman produces a relevant and overtly untruthful answer (3), which promotes an incongruity between what the speaker says and the viewer's knowledge of him and possible events, which constitute the relevant model of reference. Resolution then coincides with the recipient's acknowledging that Foreman's riposte is relevant to the preceding question on House's part and that it is purely jocular. This instance seems to represent what can be conceived of as contestive, maximally collaborative humour (Holmes 2006, cf. Coates 1989, 1996), by means of which the interlocutors jocularly challenge and try to outwit each other, yet not nurturing any ill will. The next example is similar in this respect, but House's and Wilson's brickbats (1-11) do carry relevant meanings, spilling out of the humorous frame.

\section{Example 7}

[House wheels into a hospital toilet. He has started pretending he can't walk so that Cuddy should return to him his parking space, close to the hospital building.]

1. Wilson: Ah yes, if it isn't Dr. Ironside.

2. House: Ah, if it isn't Dr. I-Had-No-Friends-When-I-Was-Growing-Up-So-All-I-Did-Was-Watch-TVBy-Myself-Which-Is-Why-I-Can-Now-Make-Constant-Pop-Culture-References-Which-No-OneUnderstands-But-Me.

3. Wilson: That's my name. Don't wear it out. [House wants to get up.] Uh uh.

4. House: [sits back down] Safe from Cuddy but I guess not from her trusted ratcomplice.

Episode 13, season 3

Each of the turns in the teasing interchange between two friends, House and Wilson, is intended to outdo the previous one, promote humour, and convey relevant meanings. In Wilson's opening turn (1), the incongruity stems from the inadequate term of address. The resolution necessitates the recognition of a cultural allusion to a character in an old television series, a chief detective on a wheelchair, which allows the recipient to realise that the speaker comments on House using a wheelchair. Should the recipient not be able to infer this meaning, he/she will find some help in House's reply (2). He constructs a lexical item constituting the addressee's surname, which is incongruous in terms of its form (cognitive model for the length and construction of surnames) and reference (cognitive model for what the addressee's name is) incongruous. This incongruity is resolved once the recipient understands that House criticises the interlocutor's rhetorical strategy. Wilson duly accepts this name (3), contrary to facts, which induces another incongruity, whose resolution comes with an understanding that he untruthful and by no means offended by the accusation. This, however, does not prevent House from verbalising another formally incongruous invective (4), a novel word, which may be understood as a blend of "rat" and "accomplice". House suggests that Wilson reports on him to Cuddy and participates in a misdemeanour.

It must once again be underscored that aggression involved in teasing is essentially humorous. In other words, a tease is typically grounded in the speaker's benevolent intentions (Dynel 2009b, 2011b). This stipulation is central to the differentiation between distinct humorous phenomena which happen to be merged in the literature, as a result of which humorous aggression and genuine aggression conducive to humour are mistakenly merged. Based on probing the speaker's intention (which is typically available to the recipients of fictional discourse) and the hearer's reaction, a distinction must be drawn between affiliative (even if ostensibly aggressive) and disaffiliative humour with respect to each hearer. Disaffiliative humour covers genuinely aggressive utterances coinciding with disparagement/putdown humour and sarcasm (e.g. Norrick 1993, Partington 2006, Dynel 2009b), which carry no humour to be enjoyed by the butt/target, at whose expense other participants are meant to be amused. Needless to say, in film talk, humour is generated primarily for the recipient's sake. 


\section{Example 8}

[House, Foreman, Thirteen (who is bisexual) and Chase are discussing their female patient's symptoms and the libido may be indicative of some disease.]

1. Foreman: Increased libido can be a symptom of adrenocortical carcinoma, which also explains her other symptoms.

2. Thirteen [annoyed]: A woman who likes sex must be sick?

3. House: Just because everybody in this room wishes that all women were horny all the time doesn't make it so. [Chase looks amused.] Get an MRI of her adrenal glands.

Episode 19, season 6

House's sarcastic turn (3) appears to carry genuine aggression against Thirteen and no humour to be appreciated by her, which is why it should be viewed as disaffiliative humour. Rather than simply dismiss her suggestion by stating that the patient's libido may not be a symptom (2), House conveys this meaning implicitly and disparages her sexual orientation. Thereby, House purposes to induce humorous responses in the other interlocutors, with at least one of them (Chase) being actually amused. It is on the same grounds that the recipients may find this utterance humorous, on provision that they are momentarily indifferent or negatively disposed towards Thirteen and affiliate with the bitingly witty speaker. Given all this, there is no denying that this instance is encompassed by superiority theory. On the other hand, incongruity may be sought primarily in the utterance's social inappropriateness (violation of the cognitive model for conversational etiquette), whilst the resolution will coincide with understanding the import and deprecating goal of House's turn.

These are a few of the widely recognised forms of conversational humour, among many other forms, which cannot be discussed for reasons of space. However, two more types of humour should be distinguished, since they are not frequently seen as representatives of conversational humour.

\subsection{Parody and non-parodic impersonation}

Parody is typically conceptualised as a literary genre or a form in art (Rossen-Knill and Henry 1997 and references therein). However, it can also be regarded as a category of conversational humour (cf. Nash 1985; Norrick 1989, 1993), albeit rare. Capitalising on verbal and non-verbal means of expression, a parodic act aims to imitate and poke fun at or mock an individual, an event, or another entity. Similar is non-parodic impersonation which involves the speaker's adoption of a voice (and hence, for instance, a change of accent or mimicry of vocal attributes) and, consequently, the humorous creation of a role, whether novel or well-known. In either case, impersonation brings to mind one of the sources of incongruity Morreall (1983) addresses, viz. one entity's seeming to be another, which may involve an individual's pretence to be someone else.

\section{Example 9}

[The previous night somebody has turned on the fire alarm in House and Wilson's flat, destroying Wilson's flat screen. Cuddy, Taub and Foreman and Chase are gathered in the diagnostic office. They all look bored.]

1. Cuddy: [sighs] is there a reason for this?

[House's ball bounces into the room. Cuddy leans over and scoops it up. House, speaking in an exaggerated French accent can be heard before he is seen entering from his office.]

2. House: Zer is a reason for everything, mes amis. I am tro-bled to report that we have a criminal in our midst.

3. Taub: Guilty of what exactly?

4. Wilson: [leaning against the kitchen area] Last night, the fire sprinklers flooded our apartment. And before that, I found an opossum in my bathtub.

5. House: [still with a French accent] You each had motive. You each had opportunity. 
6. Cuddy: This is the emergency you paged me about? [She clears her throat and stands up.]

7. House: [still with a French accent] Not so fast, Mademoiselle Cuddy. No one leaves here until they can account for their whereabouts on the evening last.

8. Cuddy: [plopping bally on his chest] Bye.

9. House: [normal voice] Okay, no one who is employed by me leaves here until they account for their whereabouts the evening last. What about you, Professor Chase?

Episode 13, season 6

The overriding incongruity in this scene arises from House's French-like pronunciation and lexical choices ("mes amis" and "Madmoiselle") in three turns $(2,5,7)$. The resolution comes (perhaps already at the stage of processing the first utterance, with the other two only testifying to the current parody-based model of reference) with the recipient's (and House's interlocutors') understanding that House performs the role of the famous Belgian detective Hercules Poirot, whose English is strongly affected by the native French language. As a result, this scene is reminiscent of the climax in any of Agatha Christie's novels featuring Poirot, when the suspects gather and wait for the detective's arrival so that he should reveal the perpetrator. In his non-parodic but allusive imitation, House means to bring to focus the similarity of the present situation to that of the ultimate revelation in a detective story resolution, as well as to display his wit.

\subsection{Non-verbal humour}

While non-verbal communication is an important component in the performance of any conversational humour and in the rendition of jokes in everyday interactions (e.g. Norrick 2001, 2004), it may be considered a distinct category of conversational humour. The way House deploys non-verbal communication tends to transcend standard means of expression, which could already be gathered, based on example 9, which involves peculiar non-verbal aspects of speech (notably, accent). The humour in the example below recruits hyperbolised facial expression and gestures.

Example 10

[Foreman, now the department's head, Cameron, Chase and House are in Diagnostics Conference Room. The previous day, Foreman has rebuked House, who had lost his licence and only helps out informally. As the team are brainstorming, House resolves to sit quietly.]

1. House: I feel like I've been inadvertently undermining your authority, so I'm just gonna observe. Not gonna say a word. [He theatrically "zips" his lips.]

2. Foreman: The heart could point to sarcoidosis.

3. [House clears his throat very loudly. With a flamboyant gesture, he pulls an x-ray from its sleeve and holds it up while looking at the ceiling.]

4. Chase: I'm thinking the x-rays indicate a lack of hilar adenopathy, which rules it out.

5. [Smiling happily, House puts the x-ray back on the table.]

6. Foreman: Staph aureus?

7. [House makes an exaggerated unhappy face, pulling his mouth downwards.]

8. Chase: No. [House looks at him tellingly and shakes his fist several times.] Because...

9. [House opens his mouth and points his finger inside.]

10. Chase: He...

11. [He closes his mouth around the tip of his finger.]

12. Chase: Smokes?

13. [House expressively drops his hand to the table and gives Chase an exasperated look.]

14. Foreman: He's miming a thermometer. He says the fever's not high enough.

15. [House makes a happy face.] [figure 1] 
16. Chase: So some other infection.

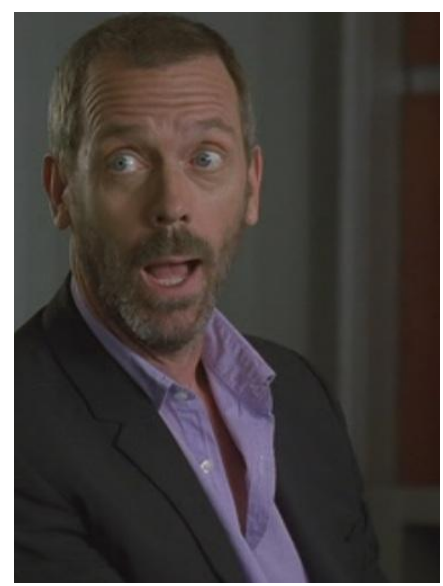

Figure 1

17. [House instantly shows him two thumbs up.]

18. Foreman: He's wrong. The fever could be misleading us into thinking infection.

19. [House sighs loudly and makes a dejected face.]

20. Foreman: Talk.

21. [House shakes his head and his finger. He mimes feeling an invisible wall.] [figure 2]

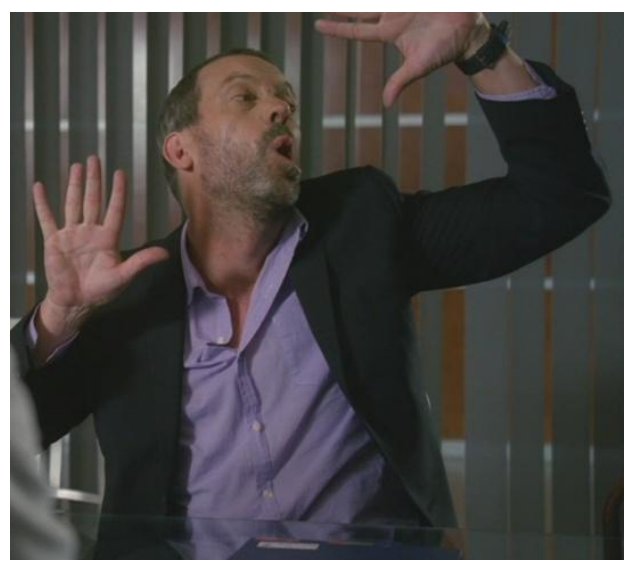

Figure 2

22. Foreman: It could all fit with lymphoma.

23. [House closes one eye, thinking. He raises his right arm so the upper arm is parallel to the floor and the forearm is pointing up. His left hand touches the right elbow. He then raises both arms over his head and drops the right one so that hand can touch the left arm.] [to Cameron] Uh, I need you to spread your legs so I can do an "H."

24. Cameron: Can't be lymphoma. LDH is normal.

25. Foreman: He's got good liver function. It's masking the elevated levels. Biopsy the lymph node. Check it out. [Cameron and Chase leave.]

26. House: Makes sense. I guess you don't need me. [He gets up to leave.] Oh, by the way, you might want to close the blinds. It's really bright in here.

27. [Foreman, puzzled, closes the blinds. "LYMPHOMA TA DA!!" Is written on them in large, black letters.]

Episode 4, season 6

Having resolved not to contribute verbally to the discussion in order not to undermine Foreman's authority, House does participate non-verbally throughout the interaction $(3,5,7$, $9,11,13,15,17,19,21,23)$, only to overtly break his vow $(23,26)$. As a matter of fact, he fails to keep his promise also with each message he relays non-verbally. All his non-verbal acts offer the interlocutors clues, provoking incongruity with his earlier commitment (the current cognitive model of reference). This incongruity can be resolved on the grounds of 
House's subversive motivation to taunt Foreman and the acknowledgement that, although the former does not verbalise his thoughts, he does convey the meanings which he would do verbally. However, even when stripped of the contextual factors, House's very expressive gestures and intense facial expression, indicative of his theatrical skill, would induce humorous effects. The humour of such hyperbolised, theatrical non-verbal messages, resembling a mime's performance, rests on the violation of the cognitive model for standard means of expression. The resolution relies merely on acknowledging this fact (mastery of a stimulus). Incidentally, the punchline of this scene coincides with Foreman's, as well as the recipient's, realisation that House has known the source of the patient's symptoms from the beginning, thanks to the written message (27). The entire scene may then be viewed in the context of superiority theory, for House appears to have outwitted Foreman.

Apart from the various forms of conversational humour, a few of which have been listed and briefly discussed here, humour in dramatic discourse may also stem from other phenomena, some not recognised in linguistic humour studies so far. Thus, they should be more carefully discussed. One of such categories is quirky behaviour, which examples 9 and 10 also illustrated.

\section{Character's quirky behaviour}

Humour in dramatic discourse may depend on a character's quirky behaviour, at a glance, evincing lack of plausibility, which should be understood as a stochastic and a normative notion (Palmer 1987). In reference to real-life standards, such behaviour is both unlikely and hardly normative, which is why it may be considered to show incongruity with the cognitive model of reference for an individual's standard behaviour or activity. Its resolution entails the recipient's realisation that such behaviour is indeed possible, albeit rare (cognitive mastery). Most importantly, characters' behaviour and actions need not infringe the code of realism, as long as their rationale is satisfactorily motivated or explained. As a result, idiosyncratic behaviours are frequently taken for granted by other characters in the fictional reality, and considered plausible in the context of the real world by recipients, as well. Such is the case of House's power of intellect and predilection for violating norms, including that of politeness.

\subsection{Power of intellect}

A salient quality of House's is his exceptional detective skills and abductive reasoning, which are of key significance to diagnosing his patients. His exceptional insight into events and people is sometimes conducive to humour appreciated by the recipient. By making surprising inferences and conjectures, House displays his phenomenal wittiness and intellectual superiority, violating the model for what an average individual can infer. Additionally, his perceptiveness sometimes promotes other humorous effects, as he exposes compromising information about others or manipulates them.

\section{Example 11}

[House walks into the diagnostics room, where Chase, Thirteen and Foreman have been working on a case, to which House is yet oblivious. Foreman is having breakfast.]

1. Chase: That means she only had one or two drinks, tops.

2. House: And there's no sign of trauma.

3. Chase: How'd you know?

4. House: Because if there was, Cuddy wouldn't have needed me to take the case.

5. Thirteen: How do you know Cuddy...? 
6. House: Foreman's the only one with the balls to take a case without checking with me, and he's still working on breakfast. Which means that the... [He takes up the patient file and puts it on his forehead as if he has the power of telepathy] $18 \ldots$ no, 17-year-old honor student -

7. Thirteen: Cuddy has a soft spot for smart girls, and they don't start drinking until second semester, senior year.

8. House: So either you think that smart women look out for each other, which means you're an idiot, or you think Cuddy's not smart, which means... well, I guess it's the same both ways.

9. Thirteen: Then how did you -

House: Picture fell out of the file. She looks smart. (...)

Episode 16, season 6

Most of the cognitive incongruities in this scene emerge as House's nearly impossible, yet imaginable, perceptiveness and power of abduction manifest themselves in several of his utterances $(2,4$, and 6). Having shared his first inference (2) with the team, correct as it turns out in the light of Chase's reply (3), House explains it by making another one (4), also correct (5). Both utterances promote surprise effects and incongruity, given the cognitive model for what an ordinary person may gather, based on the present evidence. Each of them is satisfactorily resolved on the strength of House's further elaboration (4 and 6, respectively). After the resolution stage, the recipient (as well as House's interlocutors) may better comprehend the domino-effect incongruous inferences by analysing them in reverse order, thereby also appreciating House's exceptional wit. The incongruity of the third insightful observation about the patient (that she is 17 and is an exceptional student) (6), is resolved as a more prosaic reason is revealed (10). This revelation alone may be considered incongruous, for it violates the pattern established by the previous cases. With the benefit of hindsight, House's alleged ingenious conjecture (6), coupled with the accompanying non-verbal gesture indicative of psychic powers, may be thought of as his deception of the interlocutors, as well as the recipient (see section 7). Also, thanks to all his inferences and conjectures, House has the upper hand in the conversation, with his interlocutors being the inadvertent targets, who cannot immediately grasp House's premises. Therefore, the humour discussed may also be viewed as subscribing to the superiority account.

\subsection{Inappropriate behaviour: violating norms}

House's quirkiness is manifest also in his inappropriate behaviour, as the next two examples will bear out. Such behaviour may be considered violation of etiquette norms, sometimes savouring of absurdity.

\section{Example 12}

[House is adamant that Rachel, Cuddy's four-year-old daughter be enrolled in a renowned pre-school. Wilson enters his office to find House lying on the floor and watching Rachel play "feed the monkey". Rachel is not doing to well, though.]

1. House: She's got the fine motor skills of The Hulk in oven mitts. Do you want a doodle? Do you? Feed the monkey. Cuddy puts her to bed at 7:30, which cuts way into our training time. Play date's on Friday.

[Rachel finally puts the play food in the monkey's mouth, as she is supposed to. House presses something in his hand that makes a strange clicking noise, then reaches for the doodles.]

2. Wilson: What is that?

3. House: [he puts a doodle in a cup, Rachel takes it and eats it.] Dog training clicker. Gives immediate positive reinforcement, bridging the precious seconds between desired behavior and treat delivery.

4. Wilson: House, she's not a dog. [Rachel does it again, House presses the clicker one more time.] It really seems to be working. [Rachel eats a doodle.] Does Cuddy know that Rachel's here, and that you're turning her into a schnauzer? 
5. House: I told Marina that Rachel and I are working on a secret art project for mommy. Which means that some Peds patient is about to be short one art project.

6. Wilson: The sacrifices we make for our children's education.

7. House: [petting Rachel on the head like a dog] Who's a good girl? Who's a good girl? Episode 10, season 7

First of all, it should be underscored that this scene is based on the crossroads mechanism found in jokes (Dynel 2009a, 2012b). When House first uses the clicker in this scene, the recipients, as well as Wilson (2), are at a loss to understand what he is doing. This can be conceptualised as a subservient incongruity, which is humorously resolved when House answers his interlocutor's question (3), whereby his action becomes clear but the central incongruity arises. The fundamental humorous incongruity throughout this scene can be found in House's treatment of Cuddy's daughter: training a human being, a girl, as if she were a dog, which shows in his use of a dog training clicker, in tandem with his gestures and verbal behaviour $(3,7)$. From a different perspective, this may also be viewed as incongruity with the cognitive model of reference for how children ought to be taught. It is resolved thanks to the acknowledgement that such treatment, albeit otherwise difficult to conceive of, is possible and indeed feasible given House's idiosyncratic behaviour.

Example 13

[House has lived with Dominica, who is about to leave as soon as she gets her green card. House and his team (Chase, Taub, Park and Adams) are in the diagnostics room, sitting at the table and trying to focus on a new case.]

1. Park: Should we ask?

2. Chase: Nope!

3. House: What, her? [A red-haired voluptuous woman holds a cup and walks to House to give it to him.]

4. House: Yeah, my favorite companion is retiring from "companning." So I'm interviewing replacements. Thank you... Butterscotch. Is that a family name? [In the hallway, there is a lineup of similar women waiting.]

5. Adams: How long are you gonna be using the office for sex games? Just so I can plan my day.

6. House: Sex and work? I'm not a savage. [He takes a sip of what is in the cup. He seems surprised.] I asked for a cappuccino.

7. Butterscotch: That's what this is.

8. House: No, cappuccinos got a nice, stiff foam on it. This is wetter than... oh... almost slipped there. Well, thank you, Ms. Scotch, but poor foaming's a deal breaker. Could you ask the next candidate to come in? [She exits. House is looking at his notes and some "resumes" and waits for the next one to come in.]

9. Taub: Initial exam showed no sign of trauma or subconjunctival hemorrhage.

10. Park: Lymphocytosis? ALC's in normal range, but it's in the high end of normal.

[A new woman enters the office.]

11. House: Take a seat, Fawn. And tell me, what's your favorite Woody Allen movie?

12. Fawn: Annie Hall.

13. Chase: You're interviewing hookers but not gonna talk to them about sex?

14. House: Sex is a given. They're hookers. [He takes notes.] Defend your choice.

15. Fawn: It's the most popular.

16. House [disappointed]: Ohh... that's so close. We would have accepted, "Diane Keaton looks great in suits," or, "it's a trenchant commentary on today's mores," or, "I needed the eggs." Thanks for your interest. [She gets up and leaves.]

Episode 17, season 8

Both House's co-workers and viewers are initially surprised to see an unknown woman in the doctors' office. This surprising incongruity is partly resolved in the light of House's surprising explanation (4), which invites other incongruities. One of such is why he should interview the candidates the way he does, as indicated by Chase's question (13). This incongruity is satisfactorily resolved by House's reply (14). However, the most rudimentary 
incongruity prevails: auditioning the candidates in the hospital. The only conceivable resolution rests on gaining cognitive mastery of it and acknowledging that House can do such socially unconventional/inappropriate things.

From the viewer's perspective, the incongruity also shows on the discoursal level between the topics. This involves the few turns on the medical problem with which the doctors should be concerned $(9,10)$, those related to House's personal matters between him and the candidates $(4,6-8,11,12,14,15$, and 16), as well as between him and the team on his interview $(2-6,13$, and 14). Also, what adds to this incongruity is House's changing the topic and the addressee halfway through his turns (4, 6, and 14). As a result, the recipient keeps experiencing shifts in the current model of reference for the topic at hand. It could also be observed that House participates alternating in two practically independent interactions, with the candidates and with the team members, who take the roles of bystanders to House's interviews and ratified hearers in the medical talk. Given its significance, the problem of a participatory framework ought to be addressed independently.

\subsection{Quirky participatory behaviour}

A distinct type of a character's quirky behaviour rests on their application of a participatory framework in non-dyadic interactions involving more than one hearer (e.g. Dynel 2010c, 2011a, 2011b). Numerous humorous phenomena are grounded in the nature of a participatory framework and the distribution of hearer roles. Based on examples from "Friends", it was earlier shown that some sitcom humour may be heavily dependent on the participation framework involving the viewer (Dynel 2011a). Several participation-based strategies fostering humorous effects were distinguished on the strength of the data collected, many of which can also be present in dramatic discourse. The ploys, which are conducive to other humorous effects experienced by the recipient (e.g. situational irony or deception) include: recipients' awareness of distinct interactions, either consecutive or simultaneous; recipients' recognition of overhearers (bystanders or eavesdroppers); attitudes of concealment and disguisement towards recipients; as well as characters' self-talk and inner monologues, or peculiar assignment of hearer roles. The last category is most pronounced in "House". The speaker's choice of, and attitude towards, hearers is directly responsible for humour emergence or only facilitates it, each of which exhibits innumerable manifestations. For instance, the use of euphemisms in Example 1 is motivated by the speaker's attempt at disguising the medical term in front of a child by dint of humorous euphemisms. On the other hand, the following example capitalises on pretended concealment of meaning from a ratified hearer, which is the source of humour alone and may even be thought of a novel category of conversational humour, hitherto not acknowledged in humour studies.

\section{Example 14}

[House is meeting a couple, Whitney, who is pregnant, and Geoff, who is dubious about his fatherhood. In the light of his previous conversation with her, House has reasons to believe that Geoff is not the father.]

1. Geoff: I want a paternity test.

2. House: [theatrically, sotto voce, to Whitney] Tell him that aminos are dangerous this early on in the pregnancy.

3. Whitney: Are they?

4. House: Who cares? He doesn't know.

Episode 11, season 5

Lowering one's voice is usually employed so that a chosen individual should be moved from the position of a hearer to a non-participant, who is hence oblivious to the content of the 
message conveyed. Nevertheless, what House does is speaking sotto voce (2), albeit only theatrically, so that both the addressee (Whitney) and the third party (Geoff) should hear it. Also, in his next turn (4), House treats Geoff as if he were a non-participant and reveals to him the information of which the man should not be cognisant if the lie, which he is encouraging Whitney to tell, were to succeed. Both these incongruities that emerge in the light of the cognitive model for standard participatory behaviour (speaking sotto voce while the individual from whom information is hidden is a ratified hearer, and talking about a ratified hearer as if he were a non-participant) are resolved once House's rationale is appreciated: he wants the man to know that his partner will have cheated on him and intends to disparage the woman. This is why this example subscribes also to superiority theory.

\section{Example 15}

[In the clinic room, House has been diagnosing a Mandarin woman who does not speak English and is accompanied by her daughter. House diagnoses the patient with a cold, but the girl insists that her mother has hormonal problems and demands that she be prescribed contraceptive pills. House instantly discovers that it is the girl that will use them but ultimately gives her the prescription.]

1. House: Super. In three months when you need a refill, take a bus to a free clinic. Don't wait around hoping for mom to get another sniffle. [stands upright once more, then leans closer to the Mandarin mother] Not the sharpest chopstick in the drawer, is she?

2. Mandarin Woman: [seems to happily thank him in Mandarin.]

Episode 18, season 2

The humour of the extract above stems from the fact that House addresses the woman whom he knows to be unable to understand him (1), which is the source of incongruity given the model for successful communication of meanings. Resolution comes with an understanding that this witty putdown of the third party is actually directed primarily to her and is meant to make her feel denigrated. Another humorous stimulus observed by the recipient rests on the woman's thanking him (2), having wrongly inferred that he is reassuring her that she will be fine soon, as doctors will do. This appears to be a case of a planned misunderstanding on the speaker's part, which may be thought of as deception (see section 7).

Both the examples above, as well as many others discussed earlier, can also be analysed in the light of impoliteness, which offers fertile ground for humour occurrence.

\subsection{Impoliteness}

The notion of impoliteness covers communicative strategies designed by the speaker to cause social conflict and disharmony (Culpeper et al. 2003) and performed in order to inflict heightened face damage (Bousfield 2007, 2008). The entertaining and humorous potential of impoliteness has been widely recognised in the research with reference to various types of media discourse (see Dynel 2012a), and most importantly here, the fictional discourse of films (Culpeper 1998, 2001; Dynel 2012a). It is already Palmer (1987) that observed that genuinely aggressive remarks can take the form of humour, for "the general tenor of the fiction in which we find them ensures that we will find them funny" (1987: 118). While Palmer (1987) seems to be referring to comedy discourse, the same is relevant to dramatic discourse, which is watched for entertainment, even if not necessarily for the sake of humorous experience. Impoliteness appears to coincide with disaffiliative humour and its subordinate types involving genuine aggression (discussed in section 3.2). This happens when the speaker's utterance (which can be labelled as sarcastic, deprecatory, impolite. etc.) bears a twofold meaning, i.e. humour and genuinely derogatory force to be recognised by respective hearers in multi-party interactions (Dynel 2010a, 2011g, 2012a). Nevertheless, a distinct subtype of impoliteness needs to be distinguished in the context of film discourse, in 
reference to the cases when the speaker may not wish to amuse any hearer at the intercharacter level. This is why some impoliteness cannot be classified as (speaker-intended) conversational humour, even though the recipient may indeed find it humorous, as planned by the collective sender.

From the perspective of superiority theory, the recipient, who experiences cognitive safety, takes pleasure in the target's being disparaged, which has to be facilitated by other factors so that the recipient should not sympathise with the disparaged individual. Thus, for instance, the butt is rarely shown to be offended, even if not reciprocating impoliteness. Negatively disposed towards, or at least indifferent to, the target at a given moment, the recipient will typically be amused by the speaker's manifestation of power and wit. On the other hand, the very fact that a speaker, here a doctor, deploys impoliteness in his interactions with co-workers and patients can be regarded as incongruity, understood as a deviation from a cognitive model of reference for standard conversational etiquette. This incongruity does not disappear, even from the perspective of regular viewers (similarly to House's co-workers), who grow used to it and do not seem to find it a novel interactional phenomenon. House's impoliteness does not appear to lose its sting or humorous capacity, inasmuch as it is arises unexpectedly and displays innumerable manifestations. The incongruity of impoliteness, therefore, may also reside in the creative manner in which each of the impolite utterances is uttered (Culpeper 2011). Ultimately, their ample use in film discourse does not strike the recipients as flying in the face of what is possible/imaginable although, in real-life conversations, impoliteness need not be as creative, and hence humorous.

\section{Example 16}

[House is standing at the elevator. When he sees Cuddy, he presses the down button twice. Cuddy approaches him. Throughout this interaction, House shows indifference, while Cuddy speaks firmly and angrily.]

1. Cuddy: I was expecting you in my office 20 minutes ago.

2. House: Really? Well, that's odd, because I had no intention of being in your office 20 minutes ago.

3. Cuddy: You think we have nothing to talk about?

4. House: No, just that I can't think of anything that I'd be interested in.

5. Cuddy: I sign your paychecks.

6. House: I have tenure. Are you going to grab my cane now, stop me from leaving?

7. Cuddy: That would be juvenile. [smiles maliciously] I can still fire you if you're not doing your job.

8. House: I'm here from 9 to 5.

9. Cuddy: Your billings are practically nonexistent.

10. House: Rough year.

11. Cuddy: You ignore requests for consults.

12. House: I call back. Sometimes I misdial.

13. Cuddy: You're 6 years behind on your obligation to this clinic.

14. House: See, I was right, this doesn't interest me.

15. Cuddy: 6 years, times 3 weeks; you owe me better than 4 months.

16. House: It's 5:00. I'm going home.

17. Cuddy: To what?

18. House: ... Nice.

19. Cuddy: Look, Dr. House, the only reason that I don't fire you is because your reputation still worth something to this hospital.

20. House: Excellent, we have a point of agreement. You aren't going to fire me.

21. Cuddy: I want you to do your job.

22. House: Well, like the philosopher Jagger once said, "You can't always get what you want." Episode 1, season 1

This conversational exchange between House and Cuddy is a non-humorous power struggle, in which the privileged subordinate fights verbally against his superior. All of House's contributions are anchored in incongruity, violating the norm of deference shown to the 
employer. Additionally, many of House's turns display creativity and second-order incongruities based upon it, with their resolutions based on appreciating the speaker's meanings and the interlocutors' distinct vantage points. For instance, two utterances $(2,22)$ mirror the preceding turns $(1,21)$, recruiting atypical (and incongruous) parallelisms, yet involving a shift of perspective and contradictory meanings. In a similar vein, three other turns trump the interlocutor's previous ones $(6,8,20)$, by providing overriding arguments. On the other hand, resembling the on-line structure of a joke, (12) develops in an unexpected way (ending with incongruity), admittedly representing a blatant lie. Yet another retort capitalises on an unexpected reference to an earlier contribution (14). However, making these abrupt yet witty replies, House hardly means to come over as humorous to the addressee. It is then only the recipient that may appreciate the humorousness of House's turns, while the addressee is not amused, yet does not take offence, either but replies assertively. The witty abrasiveness of House's repartee, albeit hardly imaginable in the workplace in real life, serves as a humorous stimulus, consistent with his personality.

\section{Uncanny events}

Uncanny events are related to the previous category in that they, at least to a certain extent, originate in characters' peculiar actions and utterances, yet they do not stem directly from communicative phenomena. Whilst sitcoms abound in the whole gamut of implausible events dubbed gags (Palmer 1987), depending on concatenation of coincidences, slapstick, absurdity or characters' stupidity, which are not mutually exclusive, such cannot be so widespread in dramatic discourse, owing to its (attempted) verisimilitude. Whenever surprising and implausible events typical of comedy (see Palmer 1987) are indeed found in dramatic discourse, they need to be plausibly explained, rather than being resolved within the humorous frame in accordance with the premise of fantasy assimilation. Such is the case of House's discovery that Wilson has featured in a pornographic film (episode 15, season 6), which leads to an incongruity with the cognitive model of him in the recipient's mind. This incongruity is maintained as, together with the devastated Wilson, the viewer watches, on House's computer screen, a short scene in which people, the young Wilson included, wearing animal skins and antlers are dancing around a fire. However, both in the light of Wilson's explanation and the following part of the video, the viewers realise that he does not participate in the sexual part of the film, and that his college roommate must have shot a perfectly decent film only to transform it later into a pornographic one with different actors performing the same roles. This offers a resolution of the initial incongruity.

Similar humour also originates in the childish pranks Wilson and House play on each other and the silly contests in which they engage, thanks to which humorous incongruities arise for the recipient's benefit. Such incongruities seem to arise from the inappropriateness of such behaviour on adult men's part, which simply has to be regarded as being typical of the two men. The pranks are sometimes presented in a way that boosts the viewers' humorous experience. For example, the recipients experience a humorous surprise to find a chicken on House's desk, together with Masters (episode 19, season 7). Consequently, they gain cognitive mastery of the stimulus but start nurturing expectations of a resolution at a deeper level. Equally surprised they are to see House planting fake chicken prints leading from Wilson's office, expecting that this strange behaviour (incongruity) will be explained somehow. This incongruity lingers in their minds, until viewers learn from Thirteen that House and Wilson have been holding a strange contest to see which of them will rear a chicken longer in his office, keeping Cuddy and the security in ignorance of this fact. 
While humorous events/situations are intentionally brought about by characters, similar humour may also stem from situational irony, which is not intentional from the perspective of fictional interactants.

\section{Situational irony/irony of fate}

Situational irony or irony of fate (Luciariello 1994, Colson and Gibbs 2007), which should not be mistaken for the rhetorical figure/trope, pertains to a state of the world perceived as ironic (cf. Muecke 1969, Holdcroft 1983, Attardo 2000). Ironic events mandatorily display two features: unexpectedness, and thus the element of surprise, in tandem with the component of human frailty in terms of intentionality, actions, states, and outcomes (Luciariello 1994). Therefore, situational irony subsumes several phenomena, such as coincidences, deviations from predictions, frame shifts, juxtapositions of bi-coherences, or hypocrisy (Colston and Gibbs 2007), all referring to the state of affairs or events that is the reverse of what happened or was to be expected. Luciariello (1994) lists a full spectrum of situational irony manifestations: imbalances (inconsistency or opposition in human behaviour or borne by situational elements), self- or fate-inflicted losses (when action has been taken to avoid them or when has been in a superior/advantageous position), wins (when one was bound to lose), double outcomes (a loss coupled with a win or vice versa), dramatic irony (an observer knows what a victim does not), catch-22 (all available avenues of necessary and appropriate action lead to an inevitable loss), coincidence (events have no conventional or causal basis). Needless to say, all this may concern real events (except dramatic irony) and fictional events and the reality constructed in films, series and serials. In sitcoms, instances of situational irony are aplenty but, in dramatic discourse, they are less frequent, admittedly, so that the aura of plausibility should be maintained.

Irrespective of its type, situational irony operates on an incongruity between the actual uncanny/coincidental situation/behaviour, whether verbal or non-verbal, and a cognitive model of reference for the normal, and sometimes even expected, one. However, while Gibbs (2011) suggests that the humour of dramatic irony resides in a marked conflict between expectations and reality, it is not always the case that the recipient's conscious expectations that are disconfirmed, which is germane to all humour (cf. section 2.1). Generally understood, the resolution coincides with the recipient's acknowledgement that the two events are actually possible and did happen. Also, when the recipient does not sympathise with the victim (a character who is disadvantaged by the irony of fate) and, better still, when he/she nurtures negative feelings towards the latter, superiority theory may also be applied. Thus, the recipient, who experiences cognitive safety and is in no predicament, may find situational irony on the screen humorous. By contrast, should something grave happen to an individual, especially with whom one sympathises, no humour will emerge, even from the viewer's perspective. Such is case when Wilson, head of the department of oncology, discovers he has malignant cancer (episode 18, season 8).

\section{Example 17}

[Foreman and Taub are living in the former's flat. The previous night, Taub cooked a meal for them both. Taub and Foreman are in the men's room. We see their feet and, pants down. House, Masters and Chase enter the room.]

1. House : Swollen joints, high white count, fever. Conjunctivitis. Anyone?

2. Foreman and Taub, together : Seriously?

3. House: What, you two can't think and poop at the same time? There's a life at stake here!

4. Taub : Uh... could be familial Mediterranean fever? 
5. Foreman : Not likely. That almost always presents with abdominal pain or... diarrhea. Episode 14, season 7

The utterance Foreman contributes to the diagnostic discussion (5) appears to be situationally ironic in the current context, inasmuch as he has developed the two symptoms he addresses. The incongruity here resides in the uncanny coincidence that the speaker should be talking about symptoms irrelevant to the patient that happen to be germane to his own state, as well as Taub's. The resolution resides in realising that the utterance is perfectly sensible. Since the character's misfortune is involved, superiority theory will also hold for this example, even if there is no power building or disparagement involved at the characters' level. Incidentally, the humour of this scene resides also in the fact that House sees no problem in violating a taboo and having a medical discussion (1 and 3 ) in the men's room (cf. section 4.3).

As evidenced by the example above, situational irony, apart from being a matter of events, may involve verbal behaviour, i.e. utterances. On the other hand, situational irony may be verbally acknowledged when its experiencer consciously observes it, which Barbe (1993) captures under the ambivalent label "explicit irony". In this case, however, it seems to lose some of its humorous potential, inasmuch as the interpreter (here, the recipient) does not have to infer the situational irony, which is stated by the speaker.

\section{Example 18}

[House and his team are committed to treating a patient, a man sentenced to death penalty.]

1. Cuddy: Take him back to prison. Now.

2. House: No, can't. See, ironically, I'm bound by this court order which your ace attorney got. I have to make him all better before shipping him back for the state to kill him. Is it just me, or is that weird?

Episode 2, season 2

House acknowledges the incongruous double outcome: the patient needs to be cured before he can be executed, which renders the medical help useless (2). The resolution the recipient performs is that this is indeed possible and is in accordance with the letter of the law. While the incongruity-resolution model seems to obtain, the fact that the hearer is forewarned about the irony of fate which will be reported on ("ironically") may have an impact detrimental to the humorous effects. Admittedly, this has to do with the element of surprise, which is central to humour experience. Incidentally, the humour of this scene can be attributed to House's outwitting his employer and undermining her authority.

\subsection{Dramatic irony}

The earlier mentioned dramatic irony, a distinct subtype of situational irony (Haverkate 1990, Luciariello 1994), is particularly important, because it is inherent in fictional works, such as the discourse of films and plays. In the relevant literature, a reverberating example is the classic case of Oedipus, whose cursing another character is irrelevant to his companion but of crucial importance to the audience, who can already observe the impending doom (Clark and Gerrig 1984, Kreuz and Roberts 1993, Gibbs et al. 1995, Simpson 2011). As Simpson (2011: 47) rightly observes, dramatic irony capitalises on the conceptual mismatch "between the different interactive dimensions of the same discursive event", specifically "between two different knowledge bases: the store of knowledge held by characters embedded within the story (...) [which is] is smaller than the wider knowledge base of the audience watching the story". Put simply, dramatic irony relies on "a meaning intelligible to the audience but of which the speaker is unaware" (Gibbs et al. 1995: 189). 
Little support can be given to Gibbs et al.'s (1995) and Gibbs's (2011) claim that dramatic irony is unintentional, as it is always the result of the scriptwriter's plan (Simpson 2011). This brings the discussion to the problem of two levels of communication and the fact that the interactants are not actually the authors of the interactions, which are the film crew's product (Dynel 2011b, 2011c). Looking at the character's level alone, one may indeed observe that characters do not mean dramatic irony to happen. Nor can they observe it, save characters whose knowledge is similar to the viewer's.

Dramatic irony's fundamental incongruity depends on a mismatch between the meaning a character conveys or a belief he/she nurtures (which shows in his/her action), being oblivious to some vital information, and recipients' understanding of it in the light of their broader knowledge, their cognitive model of reference (for a partly similar view, see Gibbs 2011: 108). Interestingly, while it is usually assumed that recipients have gleaned the necessary knowledge before a character presents his/her ignorance, thanks to cinematic ploys, this order may be reversed.

Example 19

[House has been talking to Eddie, his current patient's colleague, a drug dealer.]

1. Eddie: Mickey hates the stuff. He's one of the few guys I trust to watch the product overnight. They took him away an hour ago. You think he's okay?

2. House: It's an ear test. Pretty sure he'll live.

[Cut to the treatment room. Mickey is having a seizure. His leg kicks a tray table away. Taub and Foreman rush in.]

3. Taub: Pupils are constricted. Pulse is bounding!

4. Foreman: Airway's clear. Need a crash cart in here!

5. Taub: Gotta be his blood pressure. We need to get it down before he strokes out!

6. Foreman: At least we know his ears are okay.

Episode 11, season 6

This instance of dramatic irony operates on House's utterance (2), which may not appear to be indicative of dramatic irony to the viewers precisely when it is produced, but turns out to be such within seconds. Thanks to the scene cut and location shift, the recipients get an impression that the patient crashes the moment House is talking about his stability. Although the recipients may, for a second, take House's prediction to be plausible, they are faster than him to discover that he must be wrong. The central incongruity between House's belief and the facts, constituting the cognitive model of reference, is thus acknowledged and rationalised, as a result of which resolution takes place. Also, because the viewers know the patient's real state, of which House is oblivious, they may feel superior to him.

\section{Deception}

Deception is a most peculiar humour strategy in film discourse dependent on a character's intention and/or the collective sender's use of cinematic techniques (e.g. scene omission or camera angle). Deception is here understood as intentionally causing the hearer to (continue to) believe what the speaker believes to be untrue, which usually coincides with objective untruth. In other words, the speaker intends the hearer to believe to be true something the former believes to be false (e.g. Bok 1978, Mahon 2007, Dilmon 2009, see Dynel 2011h for further discussion and references). A salient type of deception is lying, which involves unequivocally untruthful utterances.

The humorous potential of lying has already been appreciated. Morreall (1983) states that people are often amused by lies, thanks to the incongruity between what is asserted and 
what is known to be the case. Morreall's claim appears to be predicated on the presupposition of the hearer's realisation that the speaker is lying. This line of argument misses the point of the pivotal goal of lying, and its model materialisation: a lie is to stay covert from the deceived hearer. However, lying and deception, on the whole, do indeed display humorous potential from the perspective of a hearer who knows that the speaker wants another hearer to be deceived, or who is initially deceived only to discover the untruthfulness and does not suffer any damage as a result. Such is the case of the recipient.

Deception in film discourse displays a number of intrinsic features. Deceptive untruthfulness is materialised at the inter-character level, when a character is (or characters are) deceived, and/or at the recipient's level, when the viewer is deceived. In addition, deception in film discourse bifurcates into two major categories, depending on whether or not the viewer is deceived, sometimes together with a character. The recipient always recognises deception at some point, which contributes to the entertaining value of film discourse, be it thanks to its suspense or humour function.

If the viewer is aware of one character being deceived by another (here, usually House), he/she takes pleasure in witnessing the strategies the latter deploys. Deception entails dexterity on the deceptive individual's part, which has an entertaining value in it, so long as it is not produced in grave circumstances or does not lead to such. Thus, such deception can be viewed as a distinct type of disaffiliative humour. The recipient's humorous experience finds its explanation in the superiority postulates championed here, together with the incongruity approach. The unknowing individual is the butt who, at least at some point, must not realise what the deceiver's beliefs, goal and rationale are. Cognisant of the deception taking place and privy to the deceiver's genuine beliefs and/or true facts, the recipient derives pleasure from the speaker's intellectual victory over the deceived (naive) individual(s). This type of deception is similar to, and may sometimes overlap with, dramatic irony, when the viewer has an advantage over a character/characters nurturing an untruthful belief. On the other hand, an incongruity is seen between the belief the speaker induces in another character and/or already induced in the deceived individual and what the recipient believes to be true, typically the truth in the fictional world, i.e. the cognitive model of reference. Also, on a more general level, incongruity can be observed between legitimate, socially appropriate behaviour and the inappropriateness of deception, even if it should not be rare or unimaginable in various spheres of life.

\section{Example 20}

[Anica, diagnosed with Munchhausen's (she fakes diseases or induces them), has been released from hospital, contrary to House's insistence that she should stay, on the grounds that she is suffering from another disease. House meets her outside the building, as she is leaving and injects her something, as nobody is watching. He walks back inside as Anica collapses and starts to seize.]

1. Foreman: So, barely out the door and she has another seizure.

2. Chase: She must have somehow grabbed insulin on the way out.

3. Foreman: Once she's stable we need to get her out of here, before she does more damage to herself.

4. Cameron: We can't. Her white count's down.

5. House: Sorry, I missed that. My hearing's been off since the Ricky Martin concert, some chulo kicked me in the head.

6. Foreman: White count, hematocrit and platelets are all off. The bone marrow's shutting down, she actually has aplastic anemia.

7. House: Say what?

8. Cameron: All her other labs show nothing that -

9. House: Labs schmabs. A good diagnostician reads between the labs.

10. Foreman: You were right. 
11. House: Hey, hey, hey, we're not here to play the blame game. These things happen. Sometimes doctors send people out on the street to die after other doctors warned them that they were sending them out on the street to die. There's no way you could know.

Episode 9, season 2

While House's team initially suspect that the patient's seizure is self-inflicted $(2,3)$, the recipient is well aware, in the light of the preceding scene, that it is House's responsibility. Even when another symptom is detected (4), judging by House's flippancy $(5,7,9,11)$, the recipient can infer that he is deceptively withholding information (see Dynel $2011 \mathrm{~h}$ and references therein), whereas he knows what the cause of the alleged anaemia is, which is indeed confirmed in a later scene. The incongruity then arises from the disparity between the team's false beliefs House promotes and the latter's belief, shared by the recipient as the cognitive model of reference, coinciding with the truth. The resolution of this incongruity resides in the recipient's recognition of House's deception and his ulterior motive to keep the patient. The recipient also shares with House a feeling of superiority to the deceived individuals

Also, deception may be more a matter of a playful put-on, which is performed for humorous effects, as a prank, rather than meeting any other covert goals.

Example 21

[In the diagnostics room, House and the team (Chase, Foreman and Thirteen) are discussing their male patient's latest symptom, lactation.]

1. House: If he can't tell his fiancee he's gay, how is he gonna tell her he's pregnant?

2. Chase: [handing the container of breast milk to Foreman] His therapists loaded him with hormones.

3. Foreman: [looking at the container] Male hormones don't make you lactate.

4. [Foreman hands the container to House, who unscrews the lid.]

5. Chase: Except they could screw up your thyroid.

6. Foreman: That was over three months ago. We just started milking him last night.

7. [House pours the breast milk into his coffee cup.]

8. Chase: So something else screwed up his thyroid. Graves, Hashimoto's.

9. [The team is watching House with looks of complete astonishment on their faces, which he seems not to notice.]

10. House: Nope. TSH was normal.

11. [House screws the lid back on the empty container and looks up at them, but he is only waiting for medical opinions and looks completely oblivious to their reactions to him putting the breast milk in his coffee.]

12. Taub: Pituitary tumor. Could also explain his libido and heart issues.

13. [House starts to take a sip of coffee, then pauses, looking at Taub. He again puts the cup to his lips, when Thirteen distracts him.]

14. Thirteen: And if the tumor's big enough, his headaches and syncope.

15. [House pauses, considering Thirteen's comment before again raising the cup to his lips. This time, Chase abruptly speaks up. The team clearly does not want House drink the coffee.]

16. Chase: Except we- we cleared him for cancer.

17. Taub: [again distracting House from the coffee] Didn't say cancer. Prolactinomas can be benign.

18. [The team watches with looks of incredulity on their faces as House actually begins to take a sip this time. But once again he pauses.]

19. House: Check his prolactin level, then MRI his pituitary.

20. [The team lingers, staring at House, and waiting to see if he will actually drink from the cup, but he gestures them to leave.]

21. [When they are gone, House grimaces and puts the cup down.]

Episode 20, season 6

The humour in the interaction above rests on a non-verbal put-on, a playful type of deception, by means of which House means to tease the team. Throughout the diagnostic discussion quoted above, House reinforces the impression in his team that he is going to drink the male 
patient's breast milk $(7,9,11,13,13,15,17,18$, and 20), which is both repulsive and humorous. House's behaviour is incongruous, insofar as it violates the cognitive model for what is acceptable. Nonetheless, gaining cognitive mastery of the stimulus, the recipient appreciates that House will not shy away from doing something improper/objectionable. While being initially deceived together with House's interlocutors, the recipient ultimately realises that House has pretended to be willing to drink the patient's breast milk, and that he is actually disgusted by it (21). This coincides with the final resolution.

On the whole, the recipient may be deceived, whether alone or in tandem with another character, following verbal and non-verbal clues provided by the deceiver and/or multi-modal cues given by the collective sender. It is only after he/she has believed something the deceiver does not believe to be true that the recipient is allowed to recognise the presence of deception and thus he/she experiences humour. The linear process of deception recognition in film discourse is reminiscent of the garden-path mechanism in jokes (Dynel 2009a, 2012b), a peculiar materialisation of the incongruity-resolution model contingent on deception. The first part of the text entails covert ambiguity. Initially, only one meaning is effortlessly recognised by the hearer, while the second part of the text (the punchline) surprisingly invalidates the interpreter's earlier inference and prompts him/her to backtrack and reprocess the initial part of the text to appreciate an alternative, hitherto unobserved, meaning congruent with the import of the punchline. Whilst deception in jokes typically operates on pragmatic and lexical ambiguity, deception in (film) discourse relies on a juxtaposition of covert untruthfulness and truthfulness, the latter being initially unavailable but finally revealed to the recipient.

It can hardly be concluded that the recipient is the butt, even though he/she is initially deceived. As is the case of jokes, which can be subsumed under the humorous frame, film deception, which may involve humour experience, is captured by the entertainment frame. Even if the recipients consciously acknowledge having been deceived, they must realise that they have suffered no losses and have faced no repercussions. On the other hand, following the same inferential path as a deceived character does, recipients may indeed perceive the character as the butt. This is because such a character is duped and outwitted by the other, the deceiver, and has to suffer the consequences.

\section{Example 22}

[House has been trying to diagnose a patient by the name of Jeff, who cannot move. He ends a discussion with his team by saying, "I have always wanted to do this". He now enters the patient's room, and injects something in the patient's thigh.]

1. House: You are healed! Rise and walk.

2. Jeff: Are you insane?

3. House: In the Bible, you just say "Yes Lord" and then, start right in on the praising.

4. Jeff: First you tell me I've got cancer, and then you tell me that my manager-- [starts making a hand gesture and realises he can actually move his hand] What did you do?

5. House: No, what did you Lord. Thymoma is a tumour in the thymus gland. It's a bit of a wimp, but he hangs with the tough guys. PRCA and an auto-immune disease called myasthenia gravis. MG causes $[\ldots]$ muscle fatigue, including respiratory problems and difficulty swallowing.

6. House: You don't need your thymus. Take it out, everything else is manageable.

7. Jeff: Manageable. I thought you just cured me.

8. House: Nuh uh, this is just diagnostic. This just erases the symptoms of MG for five or six minutes [Jeff suddenly starts wheezing again and drops on to the floor. House stands there without raising a hair] Sometimes less. This is exactly why I created nurses. [Calls out from the room] Clean up on aisle three! Episode 6, season 2

Similarly to House's interlocutor, the viewer is deceived by House's mendacious utterance (1), believing that the patient is miraculously healed thanks to one injection. Both hearers take 
the speaker's turn as truthful (and true), whilst there are no signals to the contrary, for House continues deceiving the patient that he is healed $(3,5)$ by withholding pertinent information, until later in the interaction (6). At this stage, both hearers have reasons to start believing that the speaker cannot have been truthful, if the illness is manageable, which the patient's answer indicates (7). This is followed by House's full revelation (8), thanks to which both the addressee and the recipient are fully aware of having been deceived. On the incongruityresolution account, the recipient processes the interaction as it develops only to encounter an incongruous element in the text ("manageable"), which shatters the cognitive model at hand and causes him/her to backtrack and re-analyse the preceding part of the interchange and allow for an alternative interpretation, which ultimately affords a resolution. The recipient realises that he/she has been led up the garden path by House (while, technically, the film crew is responsible), taking this to be humorous, as opposed to the target of deception.

\section{Conclusions}

This paper aimed to give insight into the types of humour prevalent in dramatic discourse, based on examples culled from "House", whose workings were presented in the light of incongruity and superiority theory. Firstly, it was argued that conversational humour is widespread in dramatic discourse, and it is widespread, albeit not as frequent, also in real-life conversations, which it tries to imitate. Conversational humour was divided into numerous subtypes along two criteria: stylistic figures (e.g. metaphor, irony, paradox, punning, or allusions) and pragmatic categories (e.g. teasing, banter, or disparagement humour/putdowns). Also, two more categories were distinguished, though rarely conceptualised as conversational humour in the literature: parody and non-verbal expression. Moreover, humour tends to emerge from a character's quirky behaviour, such as: the violation of communicative patterns and participatory norms, as well as impoliteness, or a character's exceptional power of intellect. Elements typical of situational comedy are rare, albeit by no means impossible, thanks to characters' idiosyncratic behaviour. Humour in dramatic discourse may reside in uncanny events (for instance, materialised as pranks), as well as situational irony, including dramatic irony. It is also deception, in its various manifestations, that was shown to serve humorous purposes. It must be underscored that the categories of humour listed here can overlap (e.g. impoliteness with putdown humour or deception with uncanny participatory behaviour), and they may also co-occur, adding up to the humorous potential of the scenes, as some of the examples bore out.

The incongruity-resolution model was argued to be applicable in the analysis of all the humour categories, representing the stages of the recipient's interpretation. Incongruity was shown to arise as a deviation from a cognitive model of reference to be duly resolved according to an appropriate cognitive rule, ranging from (simple) cognitive mastery of a stimulus to more complex ones. Additionally, many humour types were shown to involve aggression: disparaging conversational humour (e.g. putdowns or sarcasm) and impoliteness (which partly overlaps with the former), as well as other forms of a character's quirky behaviour, or situational irony and deception, as long as those have targets. All such forms were labelled as disaffiliative humour, which lends itself to analysis in accordance with superiority theory. Although some models of superiority theory hold otherwise (e.g. Zillmann 1983), it may be hypothesised that the enhancement of one individual over another is the driving force of disparaging humour in film talk, where the focus is on the speaker's wit and intellectual victory over other interactants. The viewer is not preoccupied with the butt's feelings, which is facilitated by the construction of interactions. In some cases, the butt's 
response is not provided at all, while in others, the individual attacked reciprocates, which boosts the humorous potential.

Humour engendered for the viewer's benefit may centre on phenomena which sometimes do not show this capacity at the inter-character level, and would not in ordinary interactions, and may be fostered by cinematic strategies (e.g. camera movement, or juxtaposition of consecutive scenes). The collective sender's application of the various humour strategies in dramatic discourse testifies to the recipients' ratified status and the extraordinary privileges conferred on them, as well as to the attempted similitude of characters' talk, which does not strike the viewers as flying in the face of logic and plausible conversational practice. The manifestations of humour in dramatic discourse may be expected to differ from those in comedy discourse, where the goal is only to amuse the recipient, even if the code of realism should be affected. Interestingly, what corroborates the similitude of film talk is that film and real-life discourses permeate each other. Scriptwriters create characters' conversations capitalising on real-life communicative norms and rules. On the other hand, viewers tend to borrow lines from films and reuse them as stock witticisms, interweaving them into their conversational exchanges, whether capitalising on their allusiveness or (deceitfully) claiming authorship of the humorous units. Two examples from House are: "Like the philosopher Jagger once said, 'You can't always get what you want"", as well as "Everybody lies", whose humour resides mainly, if not solely, in its allusiveness. Quoted wit is yet another form of humour arising from dramatic discourse.

\section{Notes}

[1] Also, Morreall (1983) claims that adult humour exploits incongruity, whilst humour appreciated by children may be based on "simple surprise" originating in something they have never experienced before. This is because having garnered more experience and knowledge and displaying a capacity for abstraction, adults assimilate new stimuli, rather than find them amusing. On the strength of the peeka-boo example, it may be intuitively felt what Morreall (1983) means under "simple surprise" in children's humour, i.e. purely sensational/perceptual changes, but the dichotomy between two humour types provokes misgivings. Adults may find humorous a relatively simple stimulus, which Morreall (1983) also appreciates, illustrating it with an example of a custom intrinsic to a different culture. The difference is that they achieve cognitive mastery of the stimulus.

[2] In his developmental humour research, McGhee juxtaposes this concept with "reality assimilation". Here, the focus is on the ideal model of humour interpretation performed by a competent adult.

[3] I would like to thank Giovannantonio Forabosco for pointing this out to me.

[4] Averse to the tenet of incongruity resolution, Oring (2003) champions the notion of appropriate incongruity, which indicates the tension between the incongruous domains. In this vein, following Apter's (1982b) postulate of cognitive synergy, i.e. two concurrent but contradictory interpretations of the same object, Wyer and Collins (1992) propose the principle of nonreplacement holding for jokes and other forms of conversational humour. Whilst offering new parlance, these proposals do not bring out the stages of incremental comprehension of humorous stimuli, as the incongruity-resolution model does, which is here believed to be fundamental in cognitive linguistic research. Also, such proposals are reminiscent of Koestler's (1964) bisociation, which is here viewed as the final stage of interpretation (see Dynel 2011e).

[5] Morreall appears to argue against the incongruity model.

\section{References}


Apter, M. (1982a). 'Fawlty Towers: A reversal theory analysis of a popular television comedy series'. Journal of Popular Culture, 16, pp. 128-138.

Apter, M. (1982b). The Experience of Motivation: The Theory of Psychological Reversals. San Diego, CA: Academic Press.

Apter, M. \& Smith, K.C.P. (1977). 'The Theory of Humorous Reversals', in A.J. Chapman \& H.C. Foot (eds.) It's a Funny Thing, Humour, New York: Pergamon.

Attardo, S. (1994). Linguistic Theories of Humor. New York: Mouton.

Attardo, S. (2000). 'Irony as relevant inappropriateness'. Journal of Pragmatics 32, pp. 793-826.

Attardo, S. (2001). Humorous Texts: A Semantic and Pragmatic Analysis. New York, NY: Mouton de Gruyter.

Attardo, S. \& Raskin, V. (1991). 'Script theory revis(it)ed: Joke similarity and joke representation model'. Humor 4, pp. 293-348.

Barbe, K. (1993). 'Isn't it ironic that, ...: Explicit irony'. Journal of Pragmatics, 6, pp. 579-590.

Bednarek, M. (2010). The Language of Fictional Television: Drama and Identity. London/New York: Continuum.

Bednarek, M. (2011). 'The stability of the televisual character: A corpus stylistic case study', in R. Piazza, M. Bednarek \& F. Rossi (eds.), Telecinematic Discourse: Approaches to the Language of Films and Television Series. Amsterdam/Philadelphia: John Benjamins, pp. 185-204.

Berger, A. (1993). An Anatomy of Humor. New Brunswick, NJ: Transaction Publishers.

Berlyne, D. (1969). 'Laughter, humor, and play', in G. Lindzey and E. Aronson (eds.), The Handbook of Social Psychology, Vol. 3, pp. 795-852. Reading, MA: Addison-Wesley.

Bok, S. (1978). Lying: Moral Choice in Public and Private Life. New York: Random House.

Haugh, M. \& Bousfield, D. (2012). 'Mock impoliteness in interactions amongst Australian and British speakers of English'. Journal of Pragmatics, 44, pp. 1099-1114.

Bousfield, D. (2007). 'Beginnings, middles and ends: A biopsy of the dynamics of impolite exchanges'. Journal of Pragmatics, 39, pp. 2185-2216.

Bousfield, D. (2008). Impoliteness in Interaction. Amsterdam: John Benjamins.

Boxer, D \& Cortés-Conde, F. (1997). 'From bonding and biting: Conversational joking and identity display'. Journal of Pragmatics, 27, pp. 275-295.

Brock, A. (2011). 'Bumcivilian. Systemic aspects of humorous communication in comedies', in R. Piazza, M. Bednarek \& F. Rossi (eds.), Telecinematic Discourse: Approaches to the Language of Films and Television Series, pp. 263-280.

Brône, G. (2008). 'Hyper- and misunderstanding in interactional humour'. Journal of Pragmatics, 40, pp. 2027-2061.

Cantor, J. \& Zillmann, D. (1973). 'Resentment toward victimized protagonists and severity of misfortunes they suffer as factors in humor appreciation'. Journal of Experimental Research in Personality, 6, pp. 321-329.

Charney, M. (2005). Comedy: A Geographic and Historical Guide. Westport, CT: Praeger.

Chiaro, D. (1992). The Language of Jokes: Analysing Verbal Play. London: Routledge.

Clark, H. \& Gerrig, R. (1984). 'On the pretense theory of irony'. Journal of Experimental Psychology: General, 113, pp. 121-126.

Coates, J. (1989). 'Gossip revisited: language in all-female groups', in Women in their Speech Communities, J. Coates and D. Cameron (eds.), 94-121. London: Longman

Coates, J. (1996). Women Talk: Conversation Between Women Friends. Oxford: Blackwell.

Coates, J. (2007). 'Talk in a play frame: More on laughter and intimacy'. Journal of Pragmatics, 39, pp. 29-49.

Colston, H. \& Gibbs, R.. (2007). 'A brief history of irony', in Irony in Language and Thought. A Cognitive Science Reader, in R. Gibbs \& H. Colston (eds.). Routledge, pp. 3-24.

Coulson, S. (2001). Semantic Leaps. Frame-Shifting and Conceptual Blending in Meaning Construction. Cambridge: Cambridge University Press.

Coulson, S., Urbach, T. \& Kutas, M. (2006). 'Looking back: Joke comprehension and the space structuring model'. Humor, 19, pp. 229-250. 
Culpeper, J, Bousfield, D.\& A. Wichmann. (2003). "Impoliteness revisited: with special reference to dynamic and prosodic aspects'. Journal of Pragmatics, 35, pp. 1545-1579.

Culpeper, J. (1998). '(Im)politeness in drama', in J. Culpeper, M. Short and P. Verdonk (eds.), Studying Drama: From Text to Context, 83-95. London: Routledge.

Culpeper, J. (2001). Language and Characterisation: People in Plays and Other Texts. London: Longman.

Culpeper, J. (2005). 'Impoliteness and entertainment in the television show: "The Weakest Link"'. Journal of Politeness Research, 1, pp. 35-72.

Culpeper, J. (2011). Impoliteness: Using Language to Cause Offence. Cambridge: Cambridge University Press.

Dalton, M. M. \& Linder, L. R. (eds). (2005). The Sitcom Reader: America Viewed and Skewed. Albany, NY: State University of New York Press.

Dews, S., Kaplan, J. \& E. Winner. (1995). 'Why not say it directly? The social functions of irony'. Discourse Processes, 19, pp. 347-367.

Dilmon, R. (2009). 'Between thinking and speaking - linguistic tools for detecting a fabrication'. Journal of Pragmatics, 41, pp. 1152-1170.

Dynel, M. (2009a). Humorous Garden-Paths: A Pragmatic-Cognitive Study. Newcastle: Cambridge Scholars Publishing.

Dynel, M. (2009b). 'Beyond a joke: Types of conversational humour'. Language and Linguistics Compass. Semantics and Pragmatics, 3, pp. 1284-1299.

Dynel, M. (2009c). 'Metaphor is a birthday cake: Metaphor as the source of humour'. Metaphoric.de 17/2009: 27-48. http://www.metaphorik.de/17/dynel.pdf

Dynel, M. (2010a). 'Friend or foe? Chandler's humour from the metarecipient's perspective', in I. Witczak-Plisiecka (ed.). Pragmatic Perspectives on Language and Linguistics 2009. Vol.II: Pragmatics of Semantically Restricted Domains. Newcastle: Cambridge Scholars Publishing, pp. 175-205.

Dynel, M. (2010b). 'How do puns bear relevance?', in Marta Kisielewska-Krysiuk, A. Piskorska \& E. Wałaszewska (eds.). Relevance Studies in Poland Vol. 3. Exploring Translation and Communication Problems. Warszawa: Wydawnictwo Uniwersytetu Warszawskiego, pp. 105124.

Dynel, M. (2010c). 'Not hearing things - Hearer/listener categories in polylogues'. mediAzioni 9. http://www.mediazioni.sitlec.unibo.it/images/stories/PDF_folder/documentpdf/2010/dynel_2010.pdf

Dynel, M. (2011a). 'I'll be there for you: On participation-based sitcom humour', in M. Dynel (ed.). The Pragmatics of Humour across Discourse Domains. Pragmatics and Beyond New Series. Amsterdam/Philadelphia: John Benjamins, pp. 311-333.

Dynel, M. (2011b). 'You talking to me?' The viewer as a ratified listener to film discourse'. Journal of Pragmatics, 43, pp. 1628-1644.

Dynel, Marta. (2011c). 'Stranger than fiction. A few methodological notes on linguistic research in film discourse'. Brno Studies in English, 37.1, pp. 41-61.

Dynel, M. (2011d). 'Joker in the pack: Towards determining the status of humorous framing in conversations', in M. Dynel (ed.). The Pragmatics of Humour across Discourse Domains. Pragmatics and Beyond New Series. Amsterdam/Philadelphia: John Benjamins, pp. 217-241.

Dynel, M. (2011e). 'Blending the incongruity-resolution model and the conceptual integration theory: The case of blends in pictorial advertising'. International Review of Pragmatics, 3.1, pp. 59-83.

Dynel, M. (2011f). 'Pragmatics and linguistic research into humour', in M. Dynel (ed.) The Pragmatics of Humour across Discourse Domains. Pragmatics and Beyond New Series. Amsterdam/Philadelphia: John Benjamins, pp. 1-15.

Dynel, M. (2011g). 'Entertaining and enraging: The functions of verbal violence in broadcast political debates', in V. Tsakona \& D. Popa (eds.). Studies in Political Humour. Amsterdam: John Benjamins, , pp. 109-133.

Dynel, M. (2011h). 'A web of deceit: A neo-Gricean view on types of verbal deception'. International Review of Pragmatics, 3.2, pp. 137-165. 
Dynel, M. (2012a). 'Setting our House in order: The workings of impoliteness in multi-party film discourse'. Journal of Politeness Research, 8, pp. 161-194.

Dynel, M. (2012b). 'Garden-paths, red lights and crossroads: On finding our way to understanding the cognitive mechanisms underlying jokes'. Israeli Journal of Humor Research: An International Journal, 1, pp. 6-28.

Dynel, M. (2012c). 'Humour on the House: Interactional construction of metaphor in film discourse', in J. Chovanec \& I. Ermida. Language and Humour in the Media. Newcastle: Cambridge Scholars Publishing, pp. 83-106.

Everts, E. (2003). 'Identifying a particular family humor style: A sociolinguistic discourse analysis'. Humor, 16, pp. 369-412.

Ferguson, M \& Ford, T. (2008). 'Disparagement humor: A theoretical and empirical review of psychoanalytic, superiority, and social identity theories'. Humor, 21, pp. 283-312.

Festinger, L. (1957). A Theory of Cognitive Dissonance. Evanston, IL: Row Peterson.

Fónagy, Ivan. (1982). 'He is only joking (joke, metaphor and language development), in F. Kiefer (ed.), Hungarian Linguistics. Amsterdam: John Benjamins, pp. 31-108.

Forabosco, G. (1992). 'Cognitive aspects of the humour process: The concept of incongruity'. Humor, 5, pp. 9-26.

Forabosco, G. (2008). 'Is the Concept of Incongruity Still a Useful Construct for the Advancement of Humor Research?'. Lodz Papers in Pragmatics, 4, pp. 45-62.

Friend, S. (2010). 'Getting carried away: Evaluating the emotional influence of fiction film'. Midwest Studies in Philosophy XXXIV: Film and the Emotions, 34, pp. 77-105.

Geyer, N. (2010). 'Teasing and ambivalent face in Japanese multi-party discourse'. Journal of Pragmatics, 42, pp. 2120-2130.

Gibbs, R. (2011). 'Are ironic acts deliberate?'. Journal of Pragmatics, 44, pp. 104-115.

Gibbs, R, J. O'Brien \& S. Doolittle. (1995). 'Inferring meanings that are not intended: speakers' intentions and irony comprehension'. Discourse Processes 20, pp. 187-203.

Grady, J, T. Oakley \& S. Coulson. (1999). 'Blending and metaphor', in G. Steen and R. Gibbs (eds), Metaphor in Cognitive Linguistics. Amsterdam/Philadelphia, pp. 101-124

Gray, J. 2006. Watching with the Simpsons: Television, Parody, and Intertextuality. London: Routledge.

Grimes, W. H. (1995). 'A theory of humor for public address: the mirth experience'. Speech Monographs, 22, pp. 217-226.

Gruner, C. (1978). Understanding Laughter: The Workings of Wit and Humor. Chicago: Nelson-Hall.

Gruner, C. R. (1997). The Game of Humor: A Comprehensive Theory of Why We Laugh. New Brunswick, NJ: Transaction Publishers.

Haugh, M. (2010). 'Jocular mockery, (dis)affiliation, and face'. Journal of Pragmatics 42, pp. 21062119.

Haugh, M. \& Bousfield, D. (2012). 'Mock impoliteness in interactions amongst Australian and British speakers of English'. Journal of Pragmatics, 44, pp. 1099-1114.

Haverkate, H. (1990). 'A speech-act analysis of irony'. Journal of Pragmatics, 14, pp. 77-109.

Hay, J. (1995). Gender and humour: Beyond a joke. Unpublished Master's thesis, Victoria University of Wellington, Wellington, New Zealand.

Hay, J. (2000). 'Functions of humor in the conversations of men and women.' Journal of Pragmatics, 32 , pp. 709-742.

Hirsch, G. (2011). 'Between irony and humor: A pragmatic model'. Pragmatics and Cognition, 19:3, pp. 530-561.

Hobbes, T. (1996 [1651] ). Leviathan. New York: Oxford University Press.

Holdcroft, D. (1983). 'Irony as trope, and irony as discourse. Poetics Today, 4, pp. 493-511.

Holmes, Janet. (2006). 'Sharing a laugh: pragmatic aspects of humour and gender in the workplace'. Journal of Pragmatics, 38, pp. 26-50.

Horton, A. (1991). Comedy/Cinema /Theory. Oxford: University of California Press.

Hurley, M., Dennett, D. \& Adams, R. (2011). Inside Jokes: Using Humor to Reverse-Engineer the Mind. The MIT Press. 
Kant, I. (1951[1790] ). Critique Of Judgment. Translated by John Bernard. New York: Hafner Publishing Company.

Kapogianni, E. (2011). 'Irony via "surrealism", in M. Dynel (ed.), The Pragmatics of Humour across Discourse Domains, Amsterdam/Philadelphia: John Benjamins, pp. 51-68.

Keith-Spiegel, P. (1972). 'Early conceptions of humour: varieties and issues', in J. Goldstein and P. McGhee (eds.), The Psychology of Humour, New York: Academic Press, pp. 3-39.

Koestler A. (1964). The Act of Creation. London: Hutchinson.

Kotthoff, H. (1996). 'Impoliteness and conversational humor'. Folia Linguistica Amsterdam/Philadelphia: John Benjamins, pp. 30, pp. 299-327.

Kotthoff, H. (1999). 'Coherent keying in conversational humour: Contextualising joint fictionalisation', in W. Bublitz, U. Lenk \& E. Ventola (eds.), Coherence in spoken and written discourse. Amsterdam: Benjamins, pp. 125-150.

Kotthoff, H. (2003). 'Responding to irony in different contexts: On cognition in conversation'. Journal of Pragmatics, 35, pp. 1387-1411.

Kotthoff, H. (2006). 'Pragmatics of performance and the analysis of conversational humor'. Humor, 19, pp. 271-304.

Kotthoff, H. (2007). 'Oral genres of humor. On the dialectic of genre knowledge and creative authoring'. Pragmatics, 12, pp. 263-296.

Kozić, M. (2012). 'Framing communication as play in the sitcom: Patterning the verbal and the nonverbal in humour', in J. Chovanec \& I. Ermida. Language and Humour in the Media. Newcastle upon Tyne : Cambridge Scholars Publishing, pp. 107 - 138.

Kozloff, S. (2000). Overhearing Film Dialogue. Berkeley: University of California Press.

Kreuz, R. \& Roberts, R. (1993). 'On satire and parody: The importance of being ironic'. Metaphor and Symbolic Activity, 8, pp. 97-109.

Kumon-Nakamura, S., Glucksberg, S. \& Brown, M. (1995). 'How about another piece of pie: The allusional pretense theory of discourse irony'. Journal of Experimental Psychology: General, 124, pp. 3-21.

LaFave, L. (1972). 'Humor judgments as a function of reference groups and identification classes', in J. Goldstein and P. McGhee (eds.), The Psychology of Humor. New York: Academic Press, pp. 195-210.

La Fave, L., Haddad, J. \& A. Maesen, William. (1976). 'Superiority, enhanced self-esteem, and perceived incongruity humor theory', in A. Chapman, \& H.Foot (eds.), Humor and Laughter: Theory, Research and Applications. New York: Wiley and Sons, pp. 63-91.

Lampert, M. \& S. Ervin-Tripp. (2006). 'Risky laughter: Teasing and self-directed joking among male and female friends'. Journal of Pragmatics, 38, pp. 51-72.

Leech, G. (1969). A Linguistic Guide to English Poetry, London: Longman

Lucariello, J. (1994). 'Situational irony: A concept of events gone awry'. Journal of Experimental Psychology: General, 123, pp. 129-145.

MacCormac, E. (1985). A Cognitive Theory of Metaphor, Cambridge: MIT Press.

Mahon, J. (2007). 'A definition of deceiving'. International Journal of Applied Philosophy, 21, pp. 181-194.

Marc, D. (1997). Comic Visions: Television Comedy and American Culture. New York, NY: Blackwell.

Martin, R. (2007). The Psychology of Humor. An Integrative Approach. Burlington, MA: Elsevier.

Martin, R., Puhlik-Doris, P., Larsen, G., Gray, J. \& Weir, K. (2003). 'Individual differences in uses of humor and their relation to psychological well-being: Development of the Humor Styles Questionnaire'. Journal of Research in Personality, 37, pp. 48-75.

McGhee, P. (1971). 'The role of operational thinking in children's comprehension of humor'. Child Development 42-3, pp. 733-744.

McGhee, P. (1972). 'On the cognitive origins of incongruity humor: Fantasy assimilation versus reality assimilation', in J. Goldstein \& P. McGhee (eds.), The Psychology of Humor. NY: Academic Press, pp. 61-80.

McGhee, P. (1979). Humor, Its Origin and Development. San Francisco: Freeman. 
Mills, B. (2005). Television Sitcom. Berkeley, CA: University of California Press.

Mills, B. (2009). The Sitcom. Edinburgh University Press. Edinburgh.

Mio, J. \& Graesser, A. (1991). 'Humor, language, and metaphor'. Metaphor and Symbol, 6, pp. 87102

Morreall, J. (1987). 'Introduction', in J. Morreall (ed), The Philosophy of Laughter and Humour, Albany, NY: State University of New York Press

Morreall, J. (1989). 'Enjoying incongruity'. Humor 2, pp. 1-18.

Morreall, J. (2008). 'Philosophy and religion', in V. Raskin (ed). The Primer of Humor Research, Berlin/New York: Mouton de Gryuter, pp. 211-242.

Morreall, J. (2009). Comic Relief: A Comprehensive Philosophy of Humor (Wiley-Blackwell.

Muecke, D. (1969). The Compass of Irony. London: Methuen.

Mulkay, M. (1988). On Humour: Its Nature And Its Place In Society. Cambridge: Polity Press.

Nash, W. (1985). The Language of Humor: Style and Technique in Comic Discourse. London: Longman.

Neale, S. \& F. Krutnik. (1990). Popular Film and Television Comedy. London: Routledge.

Nerhardt, G. (1976). 'Incongruity and funniness: Towards a new descriptive model', in A. Chapman \& H. Foot (eds.), Humour and Laughter: Theory, Research and Applications. London: Transaction Publishers, pp. 55-62.

Norrick, N. (1984). 'Stock conversational witticisms'. Journal of Pragmatics, 8, pp. 195-209.

Norrick, N. (1986). 'A frame-theoretical analysis of verbal humor: Bisociation as schema conflict'. Semiotica, 60, pp. 225-245.

Norrick, N. (1987). 'From wit to comedy: Bisociation and intertextuality'. Semiotica, 61, pp. 113-125.

Norrick, N. (1989). 'Intertextuality in Humor'. Humor, 2, pp. 117-139.

Norrick, N. (1993). Conversational Joking: Humor in Everyday Talk. Bloomington: Indiana University Press.

Norrick, N. (2001). 'On the conversational performance of narrative jokes: Toward an account of timing'. Humor 14, pp. 255-274.

Norrick, N. (2003). 'Issues in conversational joking'. Journal of Pragmatics, 35, pp. 1333-1359.

Norrick, N. (2004). 'Non-verbal humor and joke performance'. Humor 17, pp. 401-409.

Norrick, N. \& Chiaro, D. (eds.). (2009). Humor in Interaction. Amsterdam: Benjamins.

Oring, E. (2003). Engaging Humor. Urbana. IL: University of Illinois Press.

Palmer, J. (1987). The Logic of the Absurd. On Film and Television Comedy. London: BFI Publishing.

Palmer, J. (1994). Taking Humour Seriously. London: Routledge.

Partington, A. (2006). The Linguistics of Laughter. A Corpus-assisted Study of Laughter-talk. Oxon: Routledge Studies in Linguistics.

Partington, A. (2007). 'Irony and reversal of evaluation'. Journal of Pragmatics, 39, 1547-1569.

Partington, A. (2008a). 'From Wodehouse to the White House: a corpus-assisted study of play, fantasy and dramatic incongruity in comic writing and laughter-talk'. Lodz Papers in Pragmatics, 4, pp. 189-213.

Partington, A. (2008b). 'Teasing and the White House: A corpus-assisted study of face work and performing and responding to teases', Text \& Talk, 28, pp. 771-792

Pien, D. \& Rothbart, M. (1976). 'Incongruity and resolution in children's humor: A reexamination'. Child Development, 47, pp. 966-971.

Pollio, H. (1996). 'Boundaries in humor and metaphor', in J. Mio \& A. Katz (eds.), Metaphor, Implications and Applications. Mahwah: Lawrence Erlbaum Associates, pp. 231-253.

Quaglio, P. (2009). Television Dialogue: The Sitcom Friends vs. Natural Conversation. Amsterdam/Philadelphia: John Benjamins.

Ritchie, G. (2004). The Linguistic Analysis of Jokes. London: Routledge.

Rossen-Knill, D \& Richard H. (1997). 'The pragmatics of verbal parody'. Journal of Pragmatics, 27, pp. 719-752.

Rothbart, M. (1976). Incongruity, problem-solving and laughter', in A. Chapman \& H. Foot (eds.), Humour and Laughter: Theory, Research and Applications, London: Wiley, pp. 37-54. 
Ruch, W. (1992). 'Assessment of appreciation of humor: studies with the 3WD humor test'. In C. Spielberger \& J. Butcher (eds.), Advances in Personality Assessment, Vol. 9, Hillsdale, NJ: Erlbaum, pp. 27-75.

Ruch, W. (2008). 'Psychology of humor', in V. Raskin (ed.), The Primer of Humor Research, 17-100. Berlin/New York: Mouton de Gryuter.

Ruch, W \& Hehl,F. (1998). A two-mode model of humor appreciation: its relation to aesthetic appreciation and simplicity-complexity of personality', in W. Ruch (ed.), The Sense of Humor: Explorations of a Personality Characteristic. Berlin/New York: Mouton de Gruyter, pp. 109142.

Senzani, A. (2010). 'Class and gender as a laughing matter? The case of Roseanne'. Humor, 23, 229253.

Shultz, T. (1972). 'The role of incongruity and resolution in children's appreciation of cartoon humor'. Journal of Experimental Child Psychology 13, pp. 456-477.

Simpson, P. (2011). 'That's not ironic, that's just stupid: Towards an eclectic account of the discourse of irony', in M. Dynel (ed.). The Pragmatics of Humour across Discourse Domains. Pragmatics and Beyond New Series. Amsterdam/Philadelphia: John Benjamins, pp. 33-50.

Stokoe, E. (2008). 'Dispreferred actions and other interactional breaches as devices for occasioning audience laughter in television sitcoms'. Social Semiotics, 18, pp. 289-307.

Suls, J. (1972). 'A two-stage model for the appreciation of jokes and cartoons: An information processing analysis', in J. Goldstein \& P. McGhee (eds.), The Psychology of Humor. New York: Academic Press, pp. 81-100.

Suls, J. (1977). 'Cognitive and disparagement theories of humour', in A. J. Chapman \& H. Foot (eds.), It's a Funny Thing, Humour. London: Pergamon Press, pp. 41-45.

Suls, J. (1983). 'Cognitive processes in humor appreciation', in P. McGhee \& J. Goldstein (eds.) Handbook of Humor Research, vol. I, New York: Springer Verlag, pp. 39-57.

Trueth, M. (2005). Laughter in the Living Room: Television Comedy and the American Home Audience. New York, NY: Peter Lang.

Vandaele, J. (2002). 'Humor mechanisms in film comedy: Incongruity AND superiority'. Poetics Today, 23(2), pp. 221-249.

Veale, T. (2003). 'Metaphor and metonymy: The cognitive trump-Cards of linguistic humour'. A paper presented at the International Linguistic Cognitive Conference, La Rioja. ms available at http://afflatus.ucd.ie/papers/iclc2003.pdf

Veale, T, Feyaerts, K. \& Brône, G. (2006). 'The cognitive mechanisms of adversarial humor'. Humor, 19, pp. 305-340.

Wyer, R. \& Collins, J. (1992). 'A theory of humor elicitation'. Psychological Review, 99, pp. 663-688.

Zillmann, D. (1980). Anatomy of suspense', in P. H. Tannenbaum (ed.), The Entertainment Functions of Television. Hillsdale, NJ: Lawrence Erlbaum Associates, pp. 133-163.

Zillmann, D. (1983) 'Disparagement humor', in P. McGhee \& J. Goldstein (eds.), Handbook of Humor Research, Vol. 1. New York: Springer-Verlag, pp. 85-107.

Zillmann, D. (1996). 'The psychology of suspense in dramatic exposition', in P. Vorderer, H. J. Wulff, \& M. Friedrichsen (Eds.), Suspense: Conceptualizations, theoretical analyses, and empirical explorations. Mahwah, NJ: Lawrence Erlbaum Associates, pp. 199-231.

Zillmann, D. (2000). 'Humor and comedy', in D. Zillmann \& P. Vorderer. Media Entertainment: The Psychology of Its Appeal. Mahawah: Lawrence Erblaum, pp. 37-57.

Zillmann, D \& Cantor, J. (1972). 'Directionality of transitory dominance as a communication variable affecting humor appreciation'. Journal of Personality and Social Psychology, 24, pp. 191-198.

Zillmann, D. \& Cantor, J. (1976). 'A disposition theory of humor and mirth', in A. Chapman \& Hugh C. Foot (eds.), Humor and Laughter: Theory, Research and Applications. New York: Wiley and Sons, pp. 93-116.

Ziv, A. (1984). Personality and Sense of Humor. New York: Springer. 